\title{
Association Between Water, Sanitation, and Hygiene Access and the Prevalence of Soil-Transmitted Helminth and Schistosome Infections in Wolayita Zone, Ethiopia
}

Anna Elizabeth Phillips ( $\nabla$ a.phillips05@ic.ac.uk)

Imperial College London

\section{Alison K Ower \\ The End Fund \\ Kalkidan Mekete \\ Ethiopian Public Health Institute}

\section{Ewnetu Firdawek}

Ethiopian Public Health Institute

\section{Rosie Maddren}

Imperial College of Science Technology and Medicine: Imperial College London

Habtamu Belay

Ethiopian Public Health Institute

\section{Melkie Chernet}

Ethiopian Public Health Institute

Ufaysa Anjulo

Federal Ministry of Health

\section{Birhan Mengistu}

Children's Investment Fund Foundation

\section{Mihretab Salasibew}

Children's Investment Fund Foundation

\section{Roy Anderson}

Imperial College of Science Technology and Medicine: Imperial College London

\section{Research Article}

Keywords: Soil-transmitted helminths, Schistosomiasis, Water, Sanitation, \& Hygiene, WaSH, interruption of transmission

Posted Date: January 21st, 2022

DOI: https://doi.org/10.21203/rs.3.rs-1266627/v1

License: (c) (i) This work is licensed under a Creative Commons Attribution 4.0 International License. Read Full License 


\section{Abstract \\ Background}

The Geshiyaro project is a five-year intervention to assess the impact of community and school-based water, hygiene, and sanitation (WaSH) interventions on reducing infection with soil-transmitted helminths (STH) and schistosome parasites, in combination with deworming in Wolayita zone, Ethiopia.

\section{Methods}

Data on baseline STH and schistosome prevalence and the association with household and community access to improved drinking water, latrines, and handwashing facilities were obtained during a population based, cross-sectional (by age and gender) survey conducted between 2018 and 2019.

\section{Results}

Prevalence of STH was found to be $15.5 \%$ for any STH species, $9.5 \%$ for Ascaris lumbricoides, $1.8 \%$ for Trichuris trichiura, and 7.2\% for hookworm. Intestinal schistosomiasis (Schistosoma mansoni) infection prevalence was $0.85 \%$ by Kato Katz, $21.6 \%$ by POC-CCA trace positive and $13.3 \%$ trace negative. Microhaematuria was $2.8 \%$, with only $0.13 \%$ S. haematobium eggs detected in urine filtration. Increased (>30 min) time taken to collect drinking water, sharing a latrine, and lack of handwashing facilities were all associated with a greater risk of Ascaris, hookworm, and S.mansoni infection. Not disposing of infant stool at the household was significantly associated with increased risk of schistosomiasis infection. Aggregating WaSH data at the community level, showed odds of Ascaris and Trichuris infection significantly decreased as both community sanitation coverage and access to improved drinking water improved. Hookworm had reduced odds of infection as community access to drinking water expanded but there was no effect of community sanitation, however, there was a significant impact of improved household sanitation.

\section{Conclusions}

These findings demonstrate the quality of, and specific behaviours related to an individual's use of household WaSH infrastructure are likely to augment potential protection latrines can provide. Furthermore, considering an individual household's access to WaSH alone is insufficient to demonstrate association and risk with STH/schistosomiasis infection. Increased access to improved sanitation and drinking water within the whole community significantly influences exposure and gains made at the household level.

\section{Background}

Helminth infections caused by soil-transmitted helminths (STHs) and schistosome parasites (Schistosoma mansoni and Schistosoma haematobium) are among the most prevalent afflictions of humans who live in areas of poverty in tropical and subtropical areas, with the greatest numbers occurring in sub-Saharan Africa [1]. According to the World Health Organisation (WHO), more than 1.5 billion people, or $24 \%$ of the world's population, are infected with at least one species of STH and an estimated 236.6 million people require preventive treatment against schistosomiasis [2]. Due to the geographic overlap of these parasites and that school-aged children exhibit the greatest morbidity, STH and schistosomiasis control is often integrated [3]. Prolonged infection with these parasites, particularly among children can lead to school absenteeism, stunted growth, and impaired cognitive development [4-6]. The extent of such long-term 
sequelae is related to the number or burden of worms harboured by an individual [1]. Most of the morbidity, however, can be reversed or prevented by periodic Preventive Chemotherapy (PC) with anthelmintics, usually through schoolbased platforms, which has been the cornerstone control strategy since the early 2000s [7-8]. Repeated treatment is required since these helminth parasites do not induce strong acquired immunity such that post treatment reinfection can rapidly occur. As such, without a concurrent change in environmental conditions, such as improvements in sanitation and hygiene behaviours, continued exposure can result in reinfection shortly after treatment, necessitating periodic PC [9-11].

Humans are infected after ingesting eggs (Ascaris lumbricoides and Trichuris trichiura) or through penetration of the skin by larvae in the soil (hookworm) or when people contact freshwater infested with the infective cercarial stage of the human schistosome parasites (the disease caused by infection is referred to as schistosomiasis). The soil or aquatic lifecycle requirements of STH and $\mathrm{SCH}$, respectively, leave no doubt that reduction in environmental contamination through water, sanitation, and hygiene (WaSH) interventions should help eventually break transmission of infection when used in combination of high levels of repeated mass drug treatment [12]. STH can viably survive as eggs for up to several months (Ascaris and Trichuris) and as larvae for several weeks (hookworm), thus maintaining the environmental transmission beyond the temporal immunological benefits of PC [13]. Likewise for schistosomiasis, re-infection can occur within 18-24 months after treatment if a few infected individuals contaminate the environment of the intermediate snail host who in turn can release millions of infective schistosome cercariae into freshwater bodies [14].

There is debate in the literature on the ability of MDA alone to break and sustain the control of helminth infection, although model-based analyses indicate that sustained high levels of coverage can reduce the basic reproductive number of infection $\left(R_{0}\right)$ to below unity in value [15-16]. NTDs have multiple routes of transmission, therefore a combination of approaches is ideally required to complement treatment and, in addition, many other benefits to an individual's health results from improvements in hygiene, sanitation and clean water provision.

Studies of associations between worm infection and environmental and behaviour factors show improved hygiene practices and behaviours are associated with reduced risk of infections. However, the overall quality of evidence is low, partly due to complexities in measuring human behaviour that can be hard to quantify and is not necessarily consistent. Some published meta-analyses of multiple studies, however, have found that access to and use of sanitation facilities was associated with significantly lower odds of STH infection [17-19] and schistosome infection [20-21]. Association between WaSH and STH may be confounded by extrinsic factors such as high socioeconomic status and by virtue less exposure to infection [22-24], but water contact (essential for schistosome transmission) is unaffected by this [25-26]. Similarly, randomised controlled trials (RCT), which in principle are less vulnerable to bias than observational studies, evaluating the impact of sanitation interventions on STH report mixed results [27-34]. Although RCT studies recorded improvements in $\mathrm{WaSH}$ infrastructure coverage, the impacts measured were insufficient to interrupt environmental contamination and human exposure to faecal pathogens. Such studies clearly show several the challenges in demonstrating long-term behavioural change; namely, potential bias in self-reporting behaviour, measuring compliance to the intervention, household coverage (of sanitation, for example) is only effective if sufficient people in a community have access (to a latrine) [35-38] and poor sanitation maintenance can negatively influence STH transmission [10].

Mathematical modelling suggests the impact of WaSH interventions on STH transmission highly depends on the worm species as well as the pattern of individual uptake and effectiveness of the intervention in a defined community [39]. The simulations also indicated that PC could mask the impact of WaSH interventions but there is a clear added benefit in sustaining the gains made by treatment in the long term, even after being scaled down, reducing the speed of bounceback of infection to pre-intervention levels. 
There are currently no widely accepted standard methods or guidance on how to best design WaSH interventions appropriate for STH and schistosomiasis mitigation. The WHO/UNICEF Joint Monitoring Programme for Water Supply and Sanitation (JMP) provides benchmark service ladders for safe drinking water supply, disposal of human excreta, and handwashing [40]. Since the JMP criteria are not disease-specific indicators, a traffic-light ranking of the JMP service ladders, showing the potential transmission risks associated with each tier has been proposed by Campbell et al [12]. This demonstrates that STH and schistosomiasis need to be considered by their transmission routes, considering terrestrial (STH) or aquatic (schistosomiasis) species; urinary (Schistosoma haematobium) versus faecal (Schistosoma mansoni and STH) contamination; and age-prevalence-exposure interactions. Cleanliness and maintenance of sanitation is not taken into consideration by the JMP guidelines, yet it can exacerbate STH outcomes.

Ethiopia records the 13th highest disease burden for STH in sub-Saharan Africa [41]. A five-year Geshiyaro Project has been implemented in the Wolayita zone, south-west Ethiopia, investigating the impact of two sets of interventions: community-wide anthelmintic PC and provision of safe water and sanitation alongside behaviour change communication (BCC) on STH and schistosomiasis transmission interruption [42]. The objective of Geshiyaro is to provide evidence to support complementing PC with the provision of WaSH for all. This paper presents STH and schistosomiasis-specific pre-intervention thresholds for selected WaSH indicators that are most effective at reducing exposure to infection.

\section{Methods}

\section{Study overview}

The Geshiyaro project is being conducted in all 15 districts of Wolayita zone, southwest Ethiopia. Details on sampling methods and the project protocol have been published elsewhere [42], as has information on baseline census findings and infection levels including heterogeneity by community [43]. This manuscript presents the association of baseline prevalence and intensity of four common STH species: hookworms (Ancylostoma duodenale and Necator americanus), roundworm (Ascaris), and whipworm (Trichuris) and schistosomiasis (S. mansoni and haematobium) with different levels of WaSH access, collected as part of a population census, conducted prior to any intervention between 2018 and 2019.

\section{Sample size calculation}

Prevalence and intensity of both STH and schistosomiasis are being evaluated cross-sectionally through baseline, endline 1 (Year 5) and endline 2 (Year 7) mapping. For this analysis, we combined data collected in the mapping survey, which took place between October and December 2018, and the sentinel site surveys in January 2019 and FebruaryMarch 2020, all pre-treatment.

Baseline mapping took place in 130 communities (approximately $40 \%$ of communities in Wolayita) with 100 individuals surveyed per community, 20 chosen at random from five age groups: pre-SAC (0-4 years), SAC (5-14 years), adolescents (15-20 years), young adults (21-35 years) and adults $36+$ years, equally distributed by gender. Sample size calculations were powered, for children and adults separately, to have at least $70 \%$ probability of districts with true schistosomiasis prevalence of $15 \%$ classified as $10 \%$ or over, under the assumption that the lower focality of STH will lead to sufficient sample sizes calculated for schistosomiasis being sufficient for STH. Between $26 \%$ and $75 \%$ of communities were surveyed within each district, with a higher proportion of communities in small districts. The mapping survey will be repeated in the final (and fifth) year of the project to assess changes in prevalence and intensity of infection over time. A sample of 130 communities is sufficient to detect a true reduction in prevalence from $20 \%$ at baseline to $14 \%$ or below at the end of the project; from $10 \%$ at baseline to $6 \%$ or below at the end of the project; or from $5 \%$ at baseline to $2 \%$ or below at the end of the project using significance levels $\alpha=0.05$ and $\beta=0.2$. 
In addition to the cross-sectional mapping, 30 longitudinal sentinel sites were selected based on the results of the mapping stratifying by low, moderate, and high STH and schistosomiasis prevalence. The sites were selected at random from each co-endemicity category. In each site, 150 individuals were randomly selected across the same five age-groups (outlined above), resulting in an additional 4,500 individuals sampled. Sample size calculations indicated that a total of 30 sites were required to have an $80 \%$ chance of detecting a true $40 \%$ reduction in schistosomiasis, with an intra-class correlation coefficient of 0.25 , using a significance level of $\alpha=0.05$ and $\beta=0.8$.

\section{Sampling selection}

A multi-stage cluster random sampling method was used to estimate prevalence of schistosomiasis and STH. The primary sampling unit was the community, which, for the baseline mapping, was selected within each district by a simple random sample from all communities in Wolayita. Within each selected village, households were chosen using a sampling interval strategy generated using family folders at the village health post. Selected family folders were chosen according to a sampling interval number until the desired sample size was reached [44]. At each household simple random sampling was used to recruit a single individual from one of five age bands (outlined above), by gender. This same selection of individuals was used for both baseline mapping and sentinel site survey data collection, see the flow diagram of village random section and allocation of participants in Figure 1.

\section{Diagnostics}

Each participant provided a stool and urine sample on the day of enrolment. Duplicate Kato Katz were prepared from each stool sample and read within half an hour of preparation for STH (Ascaris, Trichuris and hookworm) and $S$. mansoni infection, reported as eggs per gram (epg) [45]. A point-of-care circulating cathodic antigen test ((POC-CCA) Rapid Medical Diagnostics, Pretoria, South Africa) was used on the urine sample for further $S$. mansoni investigation in addition to detection of microhaematuria using urine reagent stripes (Hemastix $®$ ), with subsequent urine filtration on haematuria-positive samples for $S$. haematobium detection. The urine, like the stool, was processed on two separate slides and read by different laboratory technicians. Samples were tracked from receipt to reading, using barcodes recorded in SurveyCTO software (Dobility, Inc; Cambridge, MA, USA).

\section{Population census and WaSH survey}

A census of all residents in five out of the 15 districts was conducted prior to the start of any intervention. Data collection occurred in October-December 2018. The census collected demographic data (age, sex, observed shoe wearing) for all individuals living in the household. Everyone present during the census visit were registered using a barcoded Geshiyaro study ID card, with those aged >=2 years registered using a biometric fingerprint if they provided consent. The head of the household, or other adult decision-maker present, completed a face-to-face interview on the household's socioeconomic information and practices and access to WaSH. Observations on water storage, latrine conditions, and handwashing facilities were made. All data, including the biometric information captured using a Vero fingerprint scanner and the Simprints app, was recorded electronically using SurveyCTO. To maximise enrolment coverage, enumerators returned up to three times to mop-up biometric registrations from those previously missed or declined. These unique identifiers enable the linking of individual census information with parasitological data and, in future, treatment at each round of MDA.

\section{Data analysis}

All analyses were performed in Stata 16 (College Station, TX, USA). The outcome of interest in this analysis was prevalence (proportion infected) and intensity of infection (eggs per gram of stool) for each parasite species (STH and schistosomiasis). All S. haematobium associations are based on diagnosis by haemastix and not urine filtration as only haematuria positive samples were filtered. Infection intensity was calculated using the arithmetic mean epg value, using both egg positive and negative values (the full probability distribution of intensity measure in the sampled population), 
across the means of duplicate Kato-Katz smears [2]. The exposure variable was household and community WaSH (sanitation, water, and hygiene) coverage. Household access to water was dichotomized as improved, or not, according to WHO/UNICEF JMP classification [40]. Drinking water was further classified into three categories: none, limited, or basic service (Table 1). Basic access was defined as an improved drinking water source, available in a round trip of $<30$ min at time of the survey, of how long it took the household to fetch water, wait, and return home. Type of latrine was recorded, which was further categorized in none, limited, or basic service as per JMP guidelines at the time of the interview. Basic hygiene was defined as access to handwashing facilities, with both water and soap observed at the time of the survey.

Table 1

JMP WaSH service ladders categories used for household WaSH anaylsis [40]

\begin{tabular}{|c|c|c|c|}
\hline $\begin{array}{l}\text { Service } \\
\text { Level* }\end{array}$ & Drinking water & Sanitation & Hygiene \\
\hline Improved & $\begin{array}{l}\text { Improved water sources, } \\
\text { includes piped water, } \\
\text { boreholes or tubewells, } \\
\text { protected dug wells, } \\
\text { protected springs, } \\
\text { rainwater, or packaged } \\
\text { water. }\end{array}$ & $\begin{array}{l}\text { Facilities that hygienically dispose of } \\
\text { excreta: flush/pour flush toilets } \\
\text { connected to sewer systems, septic } \\
\text { tanks, pit latrines with slabs (including } \\
\text { ventilated pit latrines), and composting } \\
\text { toilets. }\end{array}$ & \\
\hline Basic & $\begin{array}{l}\text { Improved source and } \\
\text { collection time }<30 \mathrm{~min} \\
\text { round trip from household }\end{array}$ & $\begin{array}{l}\text { Use of improved facilities and not } \\
\text { shared with other households }\end{array}$ & $\begin{array}{l}\text { Availability of } \\
\text { handwashing facility with } \\
\text { soap (bar, liquid, or powder } \\
\text { detergent) and water } \\
\text { available at household at } \\
\text { the time of the survey }\end{array}$ \\
\hline Limited & $\begin{array}{l}\text { Drinking water from an } \\
\text { improved source and } \\
\text { collection time }>30 \mathrm{~min} \\
\text { round trip from household }\end{array}$ & $\begin{array}{l}\text { Use of improved facilities and } \\
\text { shared with other }\end{array}$ & $\begin{array}{l}\text { Availability of a } \\
\text { handwashing facility } \\
\text { without soap and/or water } \\
\text { at household at the time of } \\
\text { the survey }\end{array}$ \\
\hline Unimproved & $\begin{array}{l}\text { Drinking water from } \\
\text { unprotected dug well or } \\
\text { unprotected spring }\end{array}$ & $\begin{array}{l}\text { Use of pit latrines without a slab or } \\
\text { platform, hanging latrines or bucket }\end{array}$ & \\
\hline No service & $\begin{array}{l}\text { Surface water: Drinking } \\
\text { water directly from a river, } \\
\text { dam, lake, pond, stream, } \\
\text { canal }\end{array}$ & $\begin{array}{l}\text { Open defecation: Disposal of human } \\
\text { faeces in open places }\end{array}$ & $\begin{array}{l}\text { No handwashing facility or } \\
\text { no water at household }\end{array}$ \\
\hline
\end{tabular}

Descriptive results were presented as percentages or means, with 95\% confidence intervals using Taylor linearization method to account for clustering within communities to account for study design and unequal selection probability. Univariate analysis of any association between dependent variables (dichotomous outcome of infected, or not) and exposure (age, sex, WaSH access), accounting for survey design using SVY method in STATA. F-statistics were calculated using adjusted Wald test for categorical variables and ANOVA for continuous variables. Multivariate logistic regression model using generalized linear mixed models was developed to check for confounding variables. Any variable with a $p$-value of $>.05$ in the simple regression was not included in the backward logistic regression model. Multilevel analysis to assess the influence of community-level effects on an individual outcome was used in addition to between group and within-group variability. The effect of WaSH on intensity of infection was analysed using a multilinear regression model, assuming a negative binomial distribution with a log link of egg counts [16]. In both 
models' covariates included sex, age, and observed shoe wearing. Standard errors were adjusted for the study design, including clustering at the community level.

\section{Results}

\section{Characteristics of the study population}

Of the 15,400 samples obtained at both baseline mapping and sentinel site surveys, sociodemographic and parasitological results were obtained for 15,133 individuals across 130 communities in 15 districts. Of those, WaSH data from the household census was linked to 6,637 individuals (Figure 1).

Table 2 describes individual and household characteristics of the survey respondents by STH species. Overall, levels of infection were $9.5 \%$ for Ascaris, $1.8 \%$ for T. trichiura, $7.2 \%$ for hookworm, and $15.5 \%$ any STH. Infection was not significantly different for any species by participant's sex. Pre-SAC were significantly more likely to be infected with Ascaris than older age groups $(\mathrm{p}<0.01)$. Similarly, hookworm was significantly higher in pre-SAC and older adults $36+$ years $(p<0.01)$ (see Table 2 and Figure 2$)$.

Most households (78.7\%) had access to improved drinking water sources where the majority accessed water from a public standpipe (54.7\%). Access to improved drinking water was not statistically associated with any STH species. Of those households that did have access to improved drinking water, only half (50.7\%) were able to collect water in less than 30 minutes round trip. Time taken to collect water did have a significant association with Ascaris and hookworm where infection was significantly higher in households that had to walk more than 30 minutes (14.7\% vs. $12.6 \%$ and $12.2 \%$ vs. $8.5 \%$, respectively). The JMP service ladder for drinking water (Table 1) considers both source and collection time. There was no association between JMP drinking water categories and STH.

Few households (15.9\%) had an improved latrine at the household, which made it difficult to analyse any association between sanitation and STH infection. Most households (76.1\%) had pit latrines without a slab, some reported no facility at all (7.7\%). Households that shared a latrine, however, was significantly associated with greater Ascaris and hookworm infection ( $16.2 \%$ vs. $13.1 \%$ and $11.1 \%$ vs. $8.6 \%$, respectively). Sanitation was categorized into the JMP service ladder (Table 1), which considers latrine type and whether it is shared with other households. There was a significant association between unimproved sanitation and increased hookworm infection $(p=0.04)$. Most households with small children reported disposing of faeces in the latrine (68.5\%). There was no statistical association between child stool disposal practices and any STH infection.

In the census respondents were asked about handwashing behaviour. Only hookworm was significantly greater among households with no handwashing facilities, with $12.3 \%$ infection in households without a place to wash hands vs. $7.8 \%$ in households with facilities. Access to soap at the handwashing facility was associated lower infection of any STH (i.e., non-species specific). Handwashing was categorized into the JMP service ladder (Table 1), which considers availability of water and soap to wash hands at the time of the survey. The lack of any handwashing facility was significantly associated with increased Ascaris, hookworm, and any STH infection. As expected, hookworm infection was significantly associated with shoe wearing, where individuals observed to be wearing shoes at the time of interview were less likely to be infected. Treatment with chlorine had a significant association with reduced Ascaris, Trichuris, and hookworm infection.

Table 3 describes individual and household characteristics by schistosomiasis prevalence. Overall, levels of infection were low for intestinal schistosomiasis (S.mansoni) by Kato Katz $(0.85 \%)$, but greater using the more sensitive diagnostic POC-CCA when trace was considered positive (21.6\%) and negative (13.1\%). Haemastix were used to detect 
microhaematuria as a proxy for urinary schistosomiasis (S. haematobium) where $2.7 \%$ of samples were positive. Urine filtration was carried out on haemastix positive samples only, where eggs were detected in $0.5 \%$ of samples only. Given the low prevalence by urine filtration, only haemastix results are presented in the tables. As has been demonstrated previously in the literature, S. mansoni (by POC-CCA) and S. haematobium (by haemastix) were significantly higher in males and SAC (see Figure 2).

Households without access to improved drinking water sources were more likely to have individuals infected with $S$. mansoni considering POC-CCA trace positive (16.2\% vs. $13.2 \%$ ). As seen with STH, there was increased risk of $S$. mansoni infection when it took the household more than 30 minutes round trip to collect water. As expected, when clustering households into the JMP service ladder for drinking water there was increased risk of schistosomiasis infection (regardless of diagnostic or species) where limited (improved source $>30 \mathrm{~min}$ round trip) or surface water was used, compared to those with basic drinking water. Treatment with chlorine had a significant association with reduced S.mansoni (by POC-CCA Tr+) infection.

There was no association with access to an improved latrine, however, sharing a latrine did have a significant association with S.mansoni (by POC-CCA Tr+) and S.haematobium (by haemastix) (19.4\% vs. $13 \%$ and $4.1 \%$ vs. $2.7 \%$, respectively). If a household did not report disposing of child stool, there was a significant association with S.mansoni (by POC-CCA Tr+) and S.haematobium (by haemastix).

Schistosome parasite infections were significantly greater in households with limited handwashing facilities (no soap and/or water available at the time of the survey). There was only association between bathing and washing clothes in fresh water with S. mansoni diagnosed using Kato Katz.

Table 4 summarises the association between community sanitation and parasitological results. No communities had an average improved sanitation coverage of more than $50 \%$. In general, individuals living in communities with lower sanitation usage had a higher prevalence and intensity of STH infection. Most communities had below $20 \%$ community sanitation coverage, where were consistently highest prevalence and intensity for all STH species. There was no statistically significant effect of community sanitation coverage on schistosomiasis prevalence or intensity.

Table 5 examines the association of community access to an improved drinking water, where lack of access had significantly higher prevalence and intensity of both STH and schistosomiasis infection again among communities in the $0-20 \%$ improved drinking water coverage category.

Table 6 shows odds ratios of infection in strata of community sanitation usage and household latrine coverage (by JMP category) with infection. The odds of Ascaris infection decreased as community sanitation coverage improved to

20-40\% (OR:0.63) and further as coverage $>40 \%$ (OR:0.35). Likewise, odds of Trichuris infection halved as community sanitation coverage reached greater than 40\% (OR:0.51). Hookworm prevalence, however, was significantly modified by household sanitation where infection increased with limited sanitation (OR:1.49) and further still with unimproved latrine (OR:1.56). There was no significant association with community coverage and hookworm.

\section{Discussion}

The analysis presented here is a baseline assessment of the association between WaSH with STH and schistosomiasis infection across a cross section of ages from pre-SAC to adults in Wolayita zone, Ethiopia. The overall prevalence of both STH and schistosomiasis in the present study was low, with higher Ascaris and hookworm infection rates among pre-SAC who have not benefitted from school-based deworming and increased exposure through environmental playing habits and less shoe wearing. 
Although was no link between household access to improved drinking water and latrine with STH, increased time taken to fetch water and sharing a latrine was statistically associated with increased Ascaris infection. This is likely a result of the poorer socio-economic status of households that are far from water access points and do not have a private household latrine. Decreased community coverage for both drinking water and sanitation was also associated with a greater risk of Ascaris (and Trichuris) prevalence and intensity. These findings indicate that household access to a latrine may only be beneficial if the wider community, specifically greater than $20 \%$, has access to improved sanitation.

There was no difference in hookworm prevalence by community access to improved drinking water and latrine, however, individuals from households with an unimproved latrine had a significantly higher prevalence compared to households without any latrine. A possible explanation for this is either sharing latrines between families has been shown to increase risk of helminth infection [46] or the confounding of latrine cleanliness and maintenance, which if improperly cleaned or maintained could be worse than open defecation since it could be a focal point for transmission [47]. The provision of latrines is only part of the improvements necessary to restrict infection, good maintenance is also required. There is a wealth of information on the type of sanitation infrastructure needed to safely remove faeces from the environment, yet many low-cost latrines fall short of basic standards because emphasis is on coverage rather than addressing continued maintenance, which if done well, encourages continued use. Future studies should explore numbers of individuals sharing latrines, as well as recording latrine maintenance and cleanliness scores to explore possible transmission pathways. Similarly, an increased risk in hookworm prevalence was observed with increased time to collect drinking water and shoe wearing.

Few households had observed handwashing facilities at the household (23.5\%), of which even fewer had soap (24.2\%). Lack of handwashing facility did have a significant association with increased risk of Ascaris, hookworm, and any STH infection.

As expected, the main age group affected by schistosome infections was SAC. Schistosome infection was also higher among males, likely due to with greater recreational water contact. Like STH, there was also a significant association with increased the time taken to collect drinking water and sharing a latrine and individuals being infected with schistosomiasis. There was significant association between greater risk of schistosomiasis infection and infant faeces were not being disposed from the household environment. This highlights the importance of infant sanitation interventions being incorporated into WaSH interventions, an element that is often overlooked. Similar to STH, there was also an increased risk of schistosomiasis in households without handwashing facilities. Surprisingly recreational (bathing or clothes washing) was statistically associated with schistosome infection. It is possible that insufficient contamination and exposure routes of transmission were considered in this present study.

Assessing the impact of WaSH interventions on infections such as STH and schistosomiasis face several challenges. These include logistical and ethical difficulties particularly when conducting randomised controlled trials, the lack of sufficient study duration to gauge long-term impact of behavioural change and the reliance on self-reporting behaviour (potentially introducing social desirability bias). Environmental influences such as floods and heavy rains can also exacerbate transmission, factors that are never considered in such analysis. Zoonotic infection via contact with animal faeces also requires consideration in future studies given the mounting evidence that human schistosome parasites and Ascaris can be zoonotic with reservoirs in livestock [48-49]. Finally, it is conceivable that the reported helminth infection prevalence is an underestimation of the "true" situation in the study area given the low intensity of infection that is hard to detect with microscopic examination of single specimens [50], which can vary considerably day-to-day [51].

Interestingly community access to improved latrines and drinking water had significant impact on both STH and schistosomiasis, respectively. Specifically, a threshold above $20 \%$ community coverage demonstrated beneficial. Often 
studies focus solely on individual access to $\mathrm{WaSH}$ at the household level, but the impact of the community as a whole is important.

There were limitations in the analysis of this study. Water quality was not considered, yet it is of great importance to understand whether chlorination is required to disinfect water containing schistosome cercariae (not necessarily the same as used for the control of coliform bacteria). Recognition of the importance of the maintenance and cleanliness of sanitation facilities, and the difficulty in measuring the impact of this, not just at the household but the influence of the wider community standards. Finally, there is a need to explore further the impact of school WaSH coverage on STH and schistosomiasis infections among SAC and the wider community [52]. Relatively few studies have investigated the impact of school-level WaSH coverage on helminth infections. A cluster-randomized trial in Kenya found that the provision of school-based WaSH improvements may reduce reinfection of STHs after school-based deworming, but the magnitude of the effects may be sex- and helminth species-specific [53]. Grimes et al constructed scores reflecting exposure to schistosomes arising from (fresh)water collection for schools and the adequacy of school sanitation and hygiene facilities. The findings were that improving school WaSH may reduce transmission of both STH and schistosomiasis, however, the impact of the different WaSH interventions was parasite dependent. In particular, the strongest associations were between water and S. mansoni, sanitation and Ascaris, and hygiene and hookworm [54]. Data was collected at the school-level for the Geshiyaro project and will be analysed in a future publication.

The WHO/UNICEF JMP criteria are useful to explore associated risk of STH/schistosomiasis infection with each tier of the service ladder. There are limitations, however, such as the lack of measurement of quality and maintenance of infrastructure and consistency of behaviour in relation to transmission routes. Finally, these results show the importance of aggregating data at the community level, rather than just individual household risk, to understand the wider impact of WaSH coverage on individual risk of infection.

\section{Conclusions}

It is widely believed that WaSH infrastructure and good practices need to be in place when scaling down a helminth NTD control programme largely based on deworming to ensure that the control/elimination of the infections is sustained when drug treatment coverage declines. WaSH also has many other benefits in addition to the control of helminth NTDs such as restricting the incidence of gut bacterial infections. Financial issues are always important in resource poor settings and questions of cost-effectiveness and measurable impact are the at the forefront of decision making in public health. Measuring that impact can be difficult since there are different types of interventions and their effectiveness and uptake by the target population can vary greatly household by household and community by community as illustrated in this study. The successful integration of WaSH into a NTD control program has already been demonstrated for trachoma using the SAFE strategy [54]. Once treatment ceases, bounce back in infection can occur very rapidly and hence gains made from PC are difficult to sustain if treatment is not repeated frequently. There is a clear need to augment PC with WaSH in preventing reinfection. However, more guidance on best-practice sanitation and hygiene promotion approaches relevant to the disease context and programme location is needed. An integrated strategy including guidelines with disease-specific indicators and targets will benefit helminth control and contribute to the evidence base of how best, and cost effectively, to implement helminth NTD control programmes.

\section{Abbreviations}

ALB

Albendazole

BCC

Behavioural change communication 
$\mathrm{Cl}$

Confidence intervals

CLTS

Community led total sanitation

EPHI

Ethiopian Public Health Institute

JMP

Joint Monitoring Programme for Water Supply and Sanitation

MDA

Mass drug administration

NTDs

Neglected tropical diseases

OWNP

One WaSH National Programme

ODF

Open defecation free

Pre-SAC

Pre-school aged children

POC-CCA

Point of care circulating cathodic antigen

PZQ

Praziquantel

PC

Preventive chemotherapy

RCT

Randomised controlled trials

SAC

School-aged children

STH

Soil-transmitted helminths

WaSH

Water, sanitation and hygiene

WHO

World Health Organisation

\section{Declarations}

\section{Ethics approval and consent to participate}

Ethical approval has been obtained from the Scientific and Ethical Review Office of the Ethiopian Public Health Institute. Permission letters have been secured from Regional and Zonal Health Offices, Educational bureaus. They have been shared with the district Health Office and community administrators and school directors. Verbal informed consent will be obtained from study participants after thorough information has been provided in the local language on the aim and procedures of the study and documented electronically through the data collection form. Assent will be obtained from school-aged children. Name and other identifiers will be excluded from the analysis for the sake of confidentiality. 
Moreover, it is the right of the participant to refuse to give information and drop out of the study at any time. Those found to be infected with STH or schistosomiasis will be given a treatment of either PZQ $40 \mathrm{mg} / \mathrm{kg}$ or ALB respectively.

School head teachers and members of school management committees provided written consent in loco parentis. A meeting with parents and school administrators at participating schools was also conducted at baseline to explain the procedures, benefits of the program, and benefits and risks to participation. Pupils provided oral assent in the trial before providing a stool sample collection.

\section{Consent for publication}

Not applicable.

\section{Availability of data and materials}

The datasets generated and/or analysed during the current study are available from the corresponding author upon reasonable request.

\section{Competing interests}

The authors declare that they have no competing interests.

\section{Funding}

Research for this paper was funded by The Children's Investment Fund Foundation ("CIFF"), UK through a grant to the London Centre for Neglected Tropical Disease Research ("LCNTDR”) at Imperial College London, UK. The views, opinions, assumptions or any other information set out in this study are solely those of the authors and should not be attributed to CIFF or any person connected with CIFF. We acknowledge joint Centre funding from the UK Medical Research Council and Department for International Development and their support to Imperial College London.

\section{Authors' contributions}

$\mathrm{AP}, \mathrm{KM}, \mathrm{AO}, \mathrm{HB}$, and $\mathrm{UA}$ were responsible for the coordination of the investigation and data collection. AP and AO were responsible for the development of the protocols and aim of the manuscript. AP and AO were responsible for the data curation and analysis. RA, KM, AP, and AO were responsible for the funding acquisition. BM, MS, KM and EF were responsible for funding management. AP wrote the paper. All authors read and approved the final manuscript.

\section{Acknowledgements}

The authors would like to thank the people of Wolaita for their participation and engagement and the Geshiyaro Project collaborators for implementation of this project, in particular World Vision Ethiopia and the Federal Ministry of Health.

\section{References}

1. Hotez PJ, Bundy DAP, Beegle K, Brooker S, Drake L, de Silva N, et al. Helminth Infections: Soil-Transmitted Helminth Infections and Schistosomiasis. In: Disease Control Priorities in Developing Countries. New York: Oxford University Press; 2006. pp. 467-82.

2. Vos T, Flaxman AD, Naghavi M, Lozano R, Michaud C, Ezzati M, et al. Years lived with disability (YLDs) for 1160 sequelae of 289 diseases and injuries 1990-2010: a systematic analysis for the Global Burden of Disease Study 2010. Lancet. 2012;380:2163-96.

3. Crompton DW. How much human helminthiasis is there in the world? J Parasitol. 1999;85:397-403. 
4. Dickson R, Awasthi S, Williamson P, Demellweek C, Garner P. Effects of treatment for intestinal helminth infection on growth and cognitive performance in children: systematic review of randomized trials. BMJ. 2000;320:1697701.

5. Taylor-Robinson DC, Jones AP, Garner P. 2007. Deworming drugs for treating soil-transmitted intestinal worms in children: effects on growth and school performance. Cochrane Database Syst Rev(4):CD000371.

6. Gulani A, Nagpal J, Osmond C, Sachdev HP. Effect of administration of intestinal anthelmintic drugs on hemoglobin: systematic review of randomized controlled trials. BMJ. 2007;334:1095.

7. World Health Organization. Helminth control in school-age children: a guide for managers of control programmes. Geneva: World Health Organization; 2011.

8. Montresor A, Crompton D, Hall A, Bundy D, Savioli L. Guidelines for the evaluation of soil-transmitted helminthiasis and schistosomiasis at community level. Geneva: World Health Organization; 1998. pp. 1-49.

9. Utzinger J, Raso G, Brooker S, de Savigny D, Tanner M, Ørnbjerg N, et al. Schistosomiasis and neglected tropical diseases: towards integrated and sustainable control and a word of caution. Parasitology. 2009;136:1859-74.

10. Asaolu SO, Ofoezie IE. The role of health education and sanitation in the control of helminth infections. Acta Trop. 2003;86:283-94.

11. Pullan RL, Freeman MC, Gething PW, Brooker SJ. Geographical inequalities in use of improved drinking water supply and sanitation across sub-Saharan Africa: mapping and spatial analysis of cross-sectional survey data. PLoS Med. 2014;11:e1001626.

12. Campbell SJ, Biritwum NK, Woods G, Velleman Y, Fleming F, Stothard JR. Tailoring Water, Sanitation, and Hygiene (WASH) Targets for Soil-Transmitted Helminthiasis and Schistosomiasis Control. Trends Parasitol. 2018;34(1):5363.

13. Else KJ, Keiser J, Holland CV, Grencis R, Sattelle D, Fujiwara R, et al. Whipworm and roundworm infections. Nat Rev Dis Primers. 2020;6:44.

14. Fulford AJ, Butterworth AE, Ouma JH, Sturrock RF. A statistical approach to schistosome population dynamics and estimation of the life-span of Schistosoma mansoni in man. Parasitology. 1995;110:307-16.

15. Anderson RM, May RM. Coevolution of hosts and parasites. Parasitology. 1982;85(2):411-26.

16. Anderson RM, May RM. Infectious Diseases of Humans. Oxford University Press; 1991.

17. Ziegelbauer K, Speich B, Mäusezahl D, Bos R, Keiser J, Utzinger J. Effect of sanitation on soil-transmitted helminth Infection: systematic review and meta-analysis. PLoS Med. 2012;9:e1001162.

18. Strunz EC, Addiss DG, Stocks ME, Ogden S, Utzinger J, Freeman MC. Water, sanitation, hygiene, and soil-transmitted helminth infection: a systematic review and meta-analysis. PLoS Med. 2014;11:e1001620.

19. Freeman MC, Stocks ME, Cumming O, Jeandron A, Higgins JP, Wolf J, et al. Hygiene and health: systematic review of handwashing practices worldwide and update of health effects. Trop Med Int Health. 2014;19:906-16.

20. Grimes JET, Croll D, Harrison WE, Utzinger J, Freeman MC, Templeton MR. The relationship between water, sanitation and schistosomiasis: a systematic review and meta-analysis. PLoS Negl Trop Dis. 2014;8:e3296.

21. Grimes JET, Croll D, Harrison WE, Utzinger J, Freeman MC, Templeton MR. The roles of water, sanitation and hygiene in reducing schistosomiasis: a review. Parasit Vectors. 2015;8:156.

22. Schmidt WP. The elusive effect of water and sanitation on the global burden of disease. Trop Med Int Health. 2014;19:522-7.

23. Bethony J, Williams JT, Kloos H, Blangero J, Alves-Fraga L, Buck G, et al. Exposure to Schistosoma mansoni infection in a rural area in Brazil. II: Household risk factors. Trop Med Int Health. 2001;6:136-45. 
24. Pullan RL, Bethony JM, Geiger SM, Cundill B, Correa-Oliveira R, Quinnell RJ, et al. Human helminth co-infection: analysis of spatial patterns and risk factors in a Brazilian community. PLoS Negl Trop Dis. 2008;2:e352.

25. Huang Y, Manderson L. Socioeconomic factors and prevalence of schistosomiasis japonica in a rural area of China. Chin J Schisto Control. 1999;11:137-42.

26. Gazzinelli A, Velasquez-Melendez G, Crawford SB, LoVerde PT, Correa-Oliveira R, Kloos H. Socioeconomic determinants of schistosomiasis in a poor rural area in Brazil. Acta Trop. 2006;99:260-71.

27. Clasen T, Boisson S, Routray P, Torondel B, Bell M, Cumming O, et al. Effectiveness of a rural sanitation programme on diarrhoea, soil-transmitted helminth infection, and child malnutrition in Odisha, India: a cluster-randomised trial. Lancet Glob Health. 2014;2:e645-53.

28. Patil SR, Arnold BF, Salvatore AL, Briceno B, Ganguly S, Colford JM Jr, et al. The effect of India's total sanitation campaign on defecation behaviors and child health in rural Madhya Pradesh: a cluster randomized con trolled trial. PLoS Med. 2014;11:e1001709.

29. Arnold BF, Null C, Luby SP, Unicomb L, Stewart CP, Dewet KG, et al. Cluster-randomised controlled trials of individual and combined water, sanitation, hygiene and nutritional interventions in rural Bangladesh and Kenya: the WASH Benefits study design and rationale. BMJ Open. 2013;3:e003476.

30. Pickering A, Njenga S, Steinbaum L, Swarthout J, Lin A, Arnold B, et al. Integrating water, sanitation, handwashing, and nutrition interventions to reduce child soil-transmitted helminth and Giardia infections: a cluster randomized controlled trial in rural Kenya. PLoS Med. 2019;16(6):e1002841.

31. Ercumen A, Benjamin-Chung J, Arnold BF, Lin A, Hubbard AE, Stewart C, et al. Effects of water, sanitation, handwashing and nutritional interventions on soil-transmitted helminth infections in young children: a clusterrandomized controlled trial in rural Bangladesh. PLoS Negl Trop Dis. 2019;13:e0007323.

32. Nery SV, McCarthy JS, Traub R, Andrews RM, Black J, Gray D, et al. A cluster-randomised controlled trial integrating a community-based water, sanitation and hygiene programme, with mass distribution of albendazole to reduce intestinal parasites in Timor-Leste: the WASH for WORMS research protocol. BMJ Open. 2015;5:e009293.

33. Nery SV, Traub RJ, McCarthy JS, Clarke NE, Amaral S, Llewellyn S, et al. WASH for WORMS: a cluster-randomized controlled trial of the impact of a community-integrated water, sanitation, and hygiene and deworming intervention on soil-transmitted helminth infections. Am J Trop Med Hyg. 2019;100:750-61.

34. Gough EK, Moulton LH, Mutasa K, Ntozini R, Stoltzfus RJ, et al. Effects of improved water, sanitation, and hygiene and improved complementary feeding on environmental enteric dysfunction in children in rural Zimbabwe: A cluster-randomized controlled trial. PLoS Negl Trop Dis. 2020;14(2):e0007963.

35. Esrey SA, Potash JB, Roberts L, Shiff C. Effects of improved water supply and sanitation on ascariasis, diarrhoea, dracunculiasis, hookworm infection, schistosomiasis, and trachoma. Bull World Health Organ. 1991;69:609-21.

36. Chongsuvivatwong V, Pas-Ong S, McNeil D, Geater A, Duerawee M. Predictors for the risk of hookworm infection: experience from endemic villages in southern Thailand. Trans R Soc Trop Med Hyg. 1996;90:630-3.

37. Yajima A, Jouquet P, Do TD, Dang TC, Tran CD, et al. High latrine coverage is not reducing the prevalence of soiltransmitted helminthiasis in Hoa Binh province, Vietnam. Trans R Soc Trop Med Hyg. 2009;103:237-41.

38. Oswald WE, Stewart AE, Kramer MR, Endeshaw T, Zerihun M, Melak B, et al. Association of community sanitation usage with soil-transmitted helminth infections among school-aged children in Amhara Region, Ethiopia. Parasit Vectors. 2017; 17;10(1):91.

39. Coffeng LE, Vaz Nery S, Gray DJ, Bakker R, de Vlas SJ, Clements ACA. Predicted short and long-term impact of deworming and water, hygiene, and sanitation on transmission of soil-transmitted helminths. PLoS Negl Trop Dis. 2018;12(12):e0006758. 
40. WHO/UNICEF WHO/UNICEF Joint Monitoring Programme (JMP) for Water Supply and Sanitation (accessed on 6. October 2021). Available online: https://washdata.org/.

41. Karagiannis-Voules DA, Biedermann P, Ekpo UF, Garba A, Langer E, Mathieu E, et al. Spatial and temporal distribution of soil-transmitted helminth infection in sub-Saharan Africa: a systematic review and geostatistical meta-analysis. The Lancet Infectious diseases. 2015;15(1):74-84.

42. Mekete K, Ower A, Dunn J, et al. The Geshiyaro Project: a study protocol for developing a scalable model of interventions for moving towards the interruption of the transmission of soil-transmitted helminths and schistosome infections in the Wolayita zone of Ethiopia. Parasit Vectors. 2019;12:503.

43. Ower AO, Mekete K, Phillips AE, Firdawek E, Dunn JD, Chernet M, et al. Patterns of soil-transmitted helminth and schistosome parasite infection at baseline in the Geshiyaro project in Wolayita Zone, Southern Ethiopia (Under review).

44. Turner AG. Sampling Strategies: Expert Group Meeting to Review the Draft Handbook on Designing Household Sample Surveys. United Nations Secretariat, Statistics Division: ESA/STAT/AC.93/2. 2003.

45. Katz N, Chaves A, Pellegrino J. A simple device for quantitative stool thick-smear technique in Schistosomiasis mansoni. Rev Inst Med Trop Sao Paulo. 1972;14:397-400.

46. Heijen M, Cumming O, Peletz R, Chan GK, Brown J, Baker K, Clasen T. Shared sanitation versus individual household latrines: a systematic review of health outcomes. PLoS One. 2014;9(4):e9330.

47. Freeman MC, Ogden S, Jacobson J, Abbott D, Addiss DG, Amnie AG, et al. Integration of water, sanitation, and hygiene for the prevention and control of neglected tropical diseases: a rationale for inter-sectoral collaboration. PLoS Negl Trop Dis. 2013;7:e2439.

48. Webster JP, Gower CM, Knowles SC, Molyneux DH, Fenton A. One health - an ecological and evolutionary framework for tackling Neglected Zoonotic Diseases. Evol Appl. 2016;9(2):8. 313-33.

49. Easton A, Gao S, Lawton SP, Bennuru S, Khan A, Dahlstrom E, Oliveira RG, Kepha S, Porcella SF, Webster J, Anderson R, Grigg ME, Davis RE, Wang J, Nutman TB. Molecular evidence of hybridization between pig and human Ascaris indicates an interbred species complex infecting humans. Elife. 2020;9:6. e61562.

50. Knopp S, Mgeni AF, Khamis IS, Steinmann P, Stothard JR, et al. Diagnosis of soil-transmitted helminths in the era of preventive chemotherapy: effect of multiple stool sampling and use of different diagnostic techniques. PLoS Negl Trop Dis. 2008;2:e331.

51. Utzinger J, Booth M, N'Goran EK, Müller I, Tanner M, et al. Relative contribution of day-to-day and intra-specimen variation in faecal egg counts of Schistosoma mansoni before and after treatment with praziquantel. Parasitology. 2001;122:537-44.

52. Freeman MC, Clasen T, Brooker S, Akoko D, Rheingans R. The impact of a school-based hygiene, water quality and sanitation intervention on soil-transmitted helminth re-infection: a cluster-randomized trial. Am J Trop Med Hyg. 2013;89:875-83.

53. Grimes JE, Tadesse G, Mekete K, Wuletaw Y, Gebretsadik A, French MD, et al. School Water, Sanitation, and Hygiene, Soil-Transmitted Helminths, and Schistosomes: National Mapping in Ethiopia. PLoS Negl Trop Dis. 2016;10(3):e0004515.

54. West SK. Blinding trachoma: prevention with the safe strategy. Am J Trop Med Hyg. 2003;69(5):18-23.

\section{Tables}

Table 1: JMP WaSH service ladders categories used for household WaSH anaylsis [40] 


\begin{tabular}{|c|c|c|c|}
\hline $\begin{array}{l}\text { Service } \\
\text { Level*}^{*}\end{array}$ & Drinking water & Sanitation & Hygiene \\
\hline Improved & $\begin{array}{l}\text { Improved water sources, } \\
\text { includes piped water, } \\
\text { boreholes or tubewells, } \\
\text { protected dug wells, } \\
\text { protected springs, } \\
\text { rainwater, or packaged } \\
\text { water. }\end{array}$ & $\begin{array}{l}\text { Facilities that hygienically dispose of } \\
\text { excreta: flush/pour flush toilets } \\
\text { connected to sewer systems, septic } \\
\text { tanks, pit latrines with slabs (including } \\
\text { ventilated pit latrines), and composting } \\
\text { toilets. }\end{array}$ & \\
\hline Basic & $\begin{array}{l}\text { Improved source and } \\
\text { collection time }<30 \mathrm{~min} \\
\text { round trip from household }\end{array}$ & $\begin{array}{l}\text { Use of improved facilities and not } \\
\text { shared with other households }\end{array}$ & $\begin{array}{l}\text { Availability of } \\
\text { handwashing facility with } \\
\text { soap (bar, liquid, or powder } \\
\text { detergent) and water } \\
\text { available at household at } \\
\text { the time of the survey }\end{array}$ \\
\hline Limited & $\begin{array}{l}\text { Drinking water from an } \\
\text { improved source and } \\
\text { collection time }>30 \mathrm{~min} \\
\text { round trip from household }\end{array}$ & $\begin{array}{l}\text { Use of improved facilities and } \\
\text { shared with other }\end{array}$ & $\begin{array}{l}\text { Availability of a } \\
\text { handwashing facility } \\
\text { without soap and/or water } \\
\text { at household at the time of } \\
\text { the survey }\end{array}$ \\
\hline Unimproved & $\begin{array}{l}\text { Drinking water from } \\
\text { unprotected dug well or } \\
\text { unprotected spring }\end{array}$ & $\begin{array}{l}\text { Use of pit latrines without a slab or } \\
\text { platform, hanging latrines or bucket }\end{array}$ & \\
\hline No service & $\begin{array}{l}\text { Surface water: Drinking } \\
\text { water directly from a river, } \\
\text { dam, lake, pond, stream, } \\
\text { canal }\end{array}$ & $\begin{array}{l}\text { Open defecation: Disposal of human } \\
\text { faeces in open places }\end{array}$ & $\begin{array}{l}\text { No handwashing facility or } \\
\text { no water at household }\end{array}$ \\
\hline
\end{tabular}

*Safely managed for drinking water or sanitation is not included as data on contamination of drinking water was not available or sewage removal for sanitation

Table 2. Bivariate analysis of STH infection by respondent characteristics and household WaSH 


\begin{tabular}{|c|c|c|c|c|c|c|c|c|c|}
\hline \multirow[t]{2}{*}{ Characteristics } & \multirow[t]{2}{*}{$\begin{array}{l}\text { Total } \\
\text { N (\%) }\end{array}$} & $\begin{array}{l}\text { Ascaris } \\
(n=1,433)\end{array}$ & \multirow[t]{2}{*}{$\mathrm{P*}$} & $\begin{array}{l}\text { Trichuris } \\
(n=269)\end{array}$ & \multirow[t]{2}{*}{$P *$} & $\begin{array}{l}\text { Hookworm } \\
(n=1,095)\end{array}$ & \multirow[t]{2}{*}{$P *$} & $\begin{array}{l}\text { Any STH } \\
(n=2,348)\end{array}$ & \multirow[t]{2}{*}{$P *$} \\
\hline & & $\%(95 \% \mathrm{Cl})$ & & $\begin{array}{l}\%(95 \% \\
\mathrm{Cl})\end{array}$ & & $\%(95 \% \mathrm{Cl})$ & & $\begin{array}{l}\%(95 \% \\
\mathrm{Cl})\end{array}$ & \\
\hline Male & $\begin{array}{l}7,249 \\
(48.9)\end{array}$ & $\begin{array}{l}8.9(8.2, \\
9.5)\end{array}$ & \multirow[t]{2}{*}{0.05} & $\begin{array}{l}1.7(1.4 \\
2.0)\end{array}$ & \multirow[t]{2}{*}{0.76} & $\begin{array}{l}7.6(7.0 \\
8.2)\end{array}$ & \multirow[t]{2}{*}{0.07} & $\begin{array}{l}15.5 \\
(14.7 \\
16.3)\end{array}$ & \multirow[t]{2}{*}{0.72} \\
\hline Female & $\begin{array}{l}7,719 \\
(51.1)\end{array}$ & $\begin{array}{l}9.8(9.7 \\
9.9)\end{array}$ & & $\begin{array}{l}1.8(1.5 \\
2.1)\end{array}$ & & $\begin{array}{l}6.8(6.3 \\
7.4)\end{array}$ & & $\begin{array}{l}15.3 \\
(14.5 \\
16.1)\end{array}$ & \\
\hline \multicolumn{10}{|c|}{ Age group (years) } \\
\hline $0-4$ & $\begin{array}{l}1,527 \\
(10.1)\end{array}$ & $\begin{array}{l}12.8(10.8, \\
14.1)\end{array}$ & \multirow[t]{5}{*}{$<0.01$} & $\begin{array}{l}2.2(1.6 \\
3.1)\end{array}$ & \multirow[t]{5}{*}{0.73} & $\begin{array}{l}9.1(7.7 \\
10.6)\end{array}$ & \multirow[t]{5}{*}{$<0.01$} & $\begin{array}{l}20.4 \\
(18.4 \\
22.5)\end{array}$ & \multirow[t]{5}{*}{0.30} \\
\hline $5-14$ & $\begin{array}{l}4,660 \\
(30.8)\end{array}$ & $\begin{array}{l}9.4(8.6 \\
10.3)\end{array}$ & & $\begin{array}{l}1.7(1.4 \\
2.1)\end{array}$ & & $\begin{array}{l}5.1(4.5 \\
5.8)\end{array}$ & & $\begin{array}{l}13.4 \\
(12.4 \\
14.4)\end{array}$ & \\
\hline $15-20$ & $\begin{array}{l}2,760 \\
(18.2)\end{array}$ & $\begin{array}{l}7.9(6.9 \\
8.9)\end{array}$ & & $\begin{array}{l}1.4(1.0 \\
1.9)\end{array}$ & & $\begin{array}{l}6.7(5.8 \\
7.7)\end{array}$ & & $\begin{array}{l}13.3 \\
(12.1 \\
15.0)\end{array}$ & \\
\hline $21-35$ & $\begin{array}{l}3,332 \\
(22.0)\end{array}$ & $\begin{array}{l}9.1(8.2 \\
10.1)\end{array}$ & & $\begin{array}{l}1.7(1.3 \\
2.2)\end{array}$ & & $\begin{array}{l}8.1(7.2 \\
9.0)\end{array}$ & & $\begin{array}{l}16.0 \\
(14.8 \\
17.3)\end{array}$ & \\
\hline$>36$ & $\begin{array}{l}2,686 \\
(17.8)\end{array}$ & $\begin{array}{l}9.4(8.3 \\
10.5)\end{array}$ & & $\begin{array}{l}1.9(1.4 \\
2.4)\end{array}$ & & $\begin{array}{l}9.3(8.3 \\
10.5)\end{array}$ & & $\begin{array}{l}17.2 \\
(15.9 \\
18.7)\end{array}$ & \\
\hline Total & & $\begin{array}{l}9.5(9.0 \\
10.0)\end{array}$ & & $\begin{array}{l}1.8(1.6, \\
2.0)\end{array}$ & & $\begin{array}{l}7.2(6.8, \\
7.7)\end{array}$ & & $\begin{array}{l}15.5 \\
(14.9 \\
16.1)\end{array}$ & \\
\hline Mean epg** & & 131.2 & & 13.4 & & 11.7 & & - & \\
\hline $\begin{array}{l}\text { Mod/Heavy } \\
\text { Infection N (\%) }\end{array}$ & & $108(7.5)$ & & $\begin{array}{l}51 \\
(19.0)\end{array}$ & & $6(0.6 \%)$ & & & \\
\hline
\end{tabular}

Acronyms: Cl, confidence interval. STH, soil-transmitted helminths.

Notes: Estimates weighted to adjust for non-response/non-availability of data on STH infections; $95 \% \mathrm{Cl}$ calculated using Taylor linearization method to account for clustering within communities.

* P values were calculated using Cochran-Mantel-Haenszel Statistics (Based on Table Scores)

** Arithmetic mean intensity calculated for those positive only 


\begin{tabular}{|c|c|c|c|c|c|c|c|c|c|}
\hline \multirow[t]{2}{*}{ Characteristics } & \multirow[t]{2}{*}{$\begin{array}{l}\text { Total } \\
\text { N (\%) }\end{array}$} & $\begin{array}{l}\text { Ascaris } \\
(n=1,433)\end{array}$ & \multirow[t]{2}{*}{$\mathrm{P} *$} & $\begin{array}{l}\text { Trichuris } \\
(\mathrm{n}=269)\end{array}$ & \multirow[t]{2}{*}{$\mathrm{P*}$} & $\begin{array}{l}\text { Hookworm } \\
(n=1,095)\end{array}$ & \multirow[t]{2}{*}{$\mathrm{P*}$} & $\begin{array}{l}\text { Any STH } \\
(n=2,348)\end{array}$ & \multirow[t]{2}{*}{$P *$} \\
\hline & & $\begin{array}{l}\%(95 \% \\
\mathrm{Cl})\end{array}$ & & $\begin{array}{l}\%(95 \% \\
\text { Cl) }\end{array}$ & & $\%(95 \% \mathrm{Cl})$ & & $\begin{array}{l}\%(95 \% \\
\mathrm{Cl})\end{array}$ & \\
\hline \multicolumn{10}{|c|}{ Household drinking water source ${ }^{\star \star \star}(n=6,637)$} \\
\hline $\begin{array}{l}\text { Has improved } \\
\text { drinking water } \\
\text { Yes } \\
\text { No }\end{array}$ & $\begin{array}{l}5,201 \\
(78.7) \\
1,408 \\
(21.3)\end{array}$ & $\begin{array}{l}14.2 \\
(13.3 \\
15.1)\end{array}$ & 0.47 & $\begin{array}{l}2.5(2.1 \\
2.9)\end{array}$ & 0.64 & $\begin{array}{l}10.6(9.8, \\
11.4) \\
9.3(8.6 \\
10.0)\end{array}$ & 0.16 & $\begin{array}{l}22.7 \\
(21.6, \\
23.9) \\
22.4 \\
(21.3, \\
23.6)\end{array}$ & 0.83 \\
\hline $\begin{array}{l}<30 \mathrm{~min} \text { to } \\
\text { water } \\
\text { Yes } \\
\text { No }\end{array}$ & $\begin{array}{l}3,323 \\
(50.7) \\
\\
3,314 \\
(49.9)\end{array}$ & $\begin{array}{l}12.6 \\
(11.5 \\
13.8) \\
14.7 \\
(13.4 \\
16.1)\end{array}$ & 0.01 & $\begin{array}{l}2.4(1.9 \\
3.1) \\
2.9(2.4 \\
3.5)\end{array}$ & 0.20 & $\begin{array}{l}8.5(7.7 \\
9.3) 12.2 \\
(11.1,13.3)\end{array}$ & $<0.01$ & $\begin{array}{l}22.0 \\
(20.7, \\
23.4) \\
23.4 \\
(22.0 \\
24.9)\end{array}$ & 0.17 \\
\hline \multirow{4}{*}{$\begin{array}{l}\text { Basic } \\
\text { Limited } \\
\text { Unimproved } \\
\text { Surface water }\end{array}$} & $\begin{array}{l}2,716 \\
(41.1)\end{array}$ & $\begin{array}{l}12.6 \\
(11.4 \\
13.9)\end{array}$ & \multirow[t]{4}{*}{0.20} & $\begin{array}{l}2.9(2.3 \\
3.6)\end{array}$ & \multirow[t]{4}{*}{0.19} & $\begin{array}{l}12.4(11.2 \\
13.7)\end{array}$ & \multirow[t]{4}{*}{0.06} & $\begin{array}{l}23.6 \\
(22.0,\end{array}$ & \multirow[t]{4}{*}{0.36} \\
\hline & $\begin{array}{l}2,485 \\
(37.6) \\
832 \\
(12.6)\end{array}$ & $\begin{array}{l}14.5 \\
(13.1 \\
15.9)\end{array}$ & & $\begin{array}{l}2.5(2.0 \\
3.2) \\
2.2(2.0 \\
3.4)\end{array}$ & & $\begin{array}{l}8.6(7.5, \\
9.7) \\
9.5(7.6, \\
11.7)\end{array}$ & & $\begin{array}{l}21.7 \\
(20.2 \\
23.4)\end{array}$ & \\
\hline & $\begin{array}{l}576 \\
(8.72)\end{array}$ & $\begin{array}{l}13.8 \\
(11.6 \\
16.3)\end{array}$ & & $\begin{array}{l}3.0(1.8 \\
4.0)\end{array}$ & & $\begin{array}{l}9.0(6.9 \\
11.7)\end{array}$ & & $\begin{array}{l}21.8 \\
(19.1 \\
24.7)\end{array}$ & \\
\hline & & $\begin{array}{l}14.8 \\
(12.1, \\
17.9)^{\prime}\end{array}$ & & & & & & $\begin{array}{l}23.4 \\
(20.2 \\
27.1)\end{array}$ & \\
\hline \multirow{3}{*}{$\begin{array}{l}\text { Treats water } \\
\text { with chlorine } \\
\text { Yes } \\
\text { No }\end{array}$} & & $\begin{array}{l}8.2(6.8 \\
9.6)\end{array}$ & \multirow[t]{3}{*}{$<0.01$} & $\begin{array}{l}0.7(0.6 \\
0.8)\end{array}$ & \multirow[t]{3}{*}{$<0.01$} & $\begin{array}{l}4.7(3.9 \\
5.5)\end{array}$ & \multirow[t]{3}{*}{$<0.01$} & $\begin{array}{l}12.9 \\
(10.7 \\
15.1)\end{array}$ & \multirow[t]{3}{*}{$<0.01$} \\
\hline & $\begin{array}{l}147 \\
(7.1)\end{array}$ & $\begin{array}{l}15.7 \\
(13.0 \\
19.0)\end{array}$ & & $\begin{array}{l}4.3(3.6 \\
5.0)\end{array}$ & & $\begin{array}{l}9.2(7.3 \\
11.1)\end{array}$ & & $\begin{array}{l}24.5 \\
(20.3 \\
287)\end{array}$ & \\
\hline & $\begin{array}{l}1,930 \\
(92.9)\end{array}$ & & & & & & & & \\
\hline
\end{tabular}

* P values were calculated using Cochran-Mantel-Haenszel Statistics (Based on Table Scores)

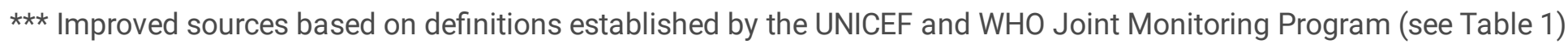




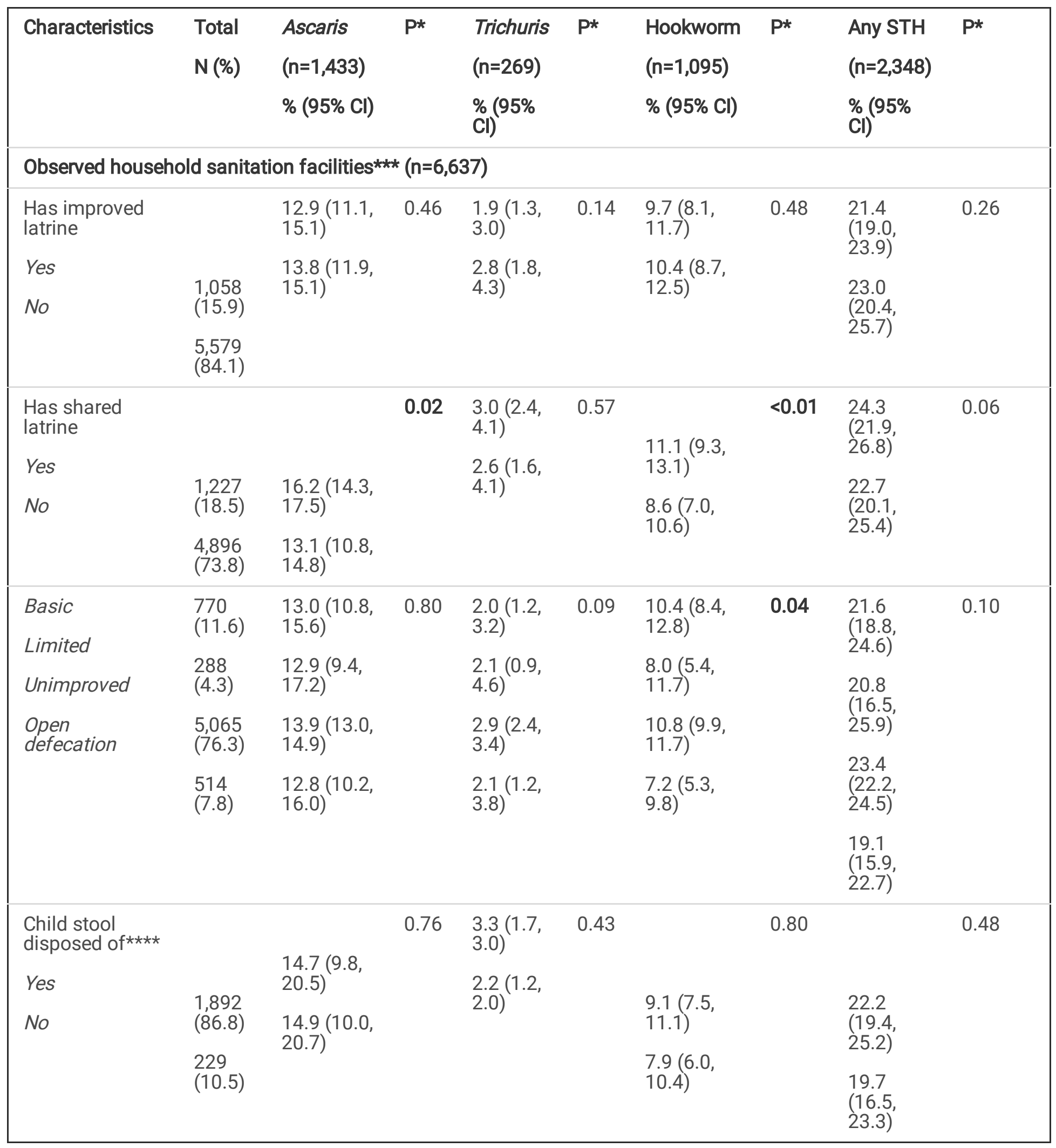

* P values were calculated using Cochran-Mantel-Haenszel Statistics (Based on Table Scores)

*** Improved sources based on definitions established by the UNICEF and WHO Joint Monitoring Program (see Table 1) ${ }^{\star * \star * C h i l d ~ s t o o l ~ d i s p o s a l ~ i n c l u d e s ~ t h e ~ c h i l d ~ u s i n g ~ t h e ~ l a t r i n e ~ d i r e c t l y ~ o r ~ d i s p o s i n g ~ f a e c e s ~ i n ~ t h e ~ l a t r i n e, ~ d r a i n / d i t c h, ~ o r ~}$ throwing it in the garbage. It does not include burying faeces in the compound or leaving it out in the open. 


\begin{tabular}{|c|c|c|c|c|c|c|c|c|c|}
\hline \multirow[t]{2}{*}{ Characteristics } & \multirow[t]{2}{*}{$\begin{array}{l}\text { Total } \\
\mathrm{N}(\%)\end{array}$} & $\begin{array}{l}\text { Ascaris } \\
(n=1,433)\end{array}$ & \multirow[t]{2}{*}{$\mathrm{P}^{*}$} & $\begin{array}{l}\text { Trichuris } \\
(n=269)\end{array}$ & \multirow[t]{2}{*}{$P^{*}$} & $\begin{array}{l}\text { Hookworm } \\
(n=1,095)\end{array}$ & \multirow[t]{2}{*}{$P^{*}$} & \multirow{2}{*}{$\begin{array}{l}(n=2,348) \\
\%(95 \% \\
\text { Cl) }\end{array}$} & \multirow[t]{2}{*}{$P^{*}$} \\
\hline & & $\%(95 \% \mathrm{Cl})$ & & $\begin{array}{l}(n=209) \\
\%(95 \%\end{array}$ & & $\%(95 \% \mathrm{Cl})$ & & & \\
\hline \multicolumn{10}{|c|}{ Observed household handwashing facilities*** $(n=6,637)$} \\
\hline $\begin{array}{l}\text { Handwashing } \\
\text { facility }<3 \mathrm{~m} \\
\text { from latrine }\end{array}$ & & $\begin{array}{l}\text { 15.2 (8.5, } \\
23.0)\end{array}$ & \multirow[t]{3}{*}{0.10} & $\begin{array}{l}2.3(1.7 \\
2.8)\end{array}$ & \multirow[t]{3}{*}{0.40} & $\begin{array}{l}7.8(6.0 \\
10.3)\end{array}$ & \multirow[t]{3}{*}{$<0.01$} & $\begin{array}{l}21.5 \\
(16.1, \\
27.9)^{\prime}\end{array}$ & \multirow[t]{3}{*}{0.08} \\
\hline \multirow[t]{2}{*}{ No } & $\begin{array}{l}1,059 \\
(23.5)\end{array}$ & $\begin{array}{l}13.2(7.4 \\
20.0)\end{array}$ & & $\begin{array}{l}2.9(2.1 \\
3.5)\end{array}$ & & $\begin{array}{l}\text { 12.3 (10.6, } \\
16.2)\end{array}$ & & \multirow[t]{2}{*}{$\begin{array}{l}24.2 \\
(18.8 \\
30.6)\end{array}$} & \\
\hline & $\begin{array}{l}3,440 \\
(76.5)\end{array}$ & & & & & & & & \\
\hline \multirow{4}{*}{$\begin{array}{l}\text { Water \& soap at } \\
\text { handwashing } \\
\text { facility } \\
\text { Yes } \\
\text { No }\end{array}$} & & $\begin{array}{l}10.5(8.6 \\
13.5)\end{array}$ & \multirow[t]{4}{*}{0.21} & $\begin{array}{l}3.1(2.2 \\
4.6)\end{array}$ & \multirow[t]{4}{*}{0.91} & $\begin{array}{l}6.2(4.3, \\
8.6)\end{array}$ & \multirow[t]{4}{*}{0.19} & \multirow{4}{*}{$\begin{array}{l}17.1 \\
(15.2 \\
19.3) \\
21.9 \\
(19.5 \\
24.7)\end{array}$} & \multirow[t]{4}{*}{0.01} \\
\hline & & \multirow[t]{3}{*}{$\begin{array}{l}14.5(13.3 \\
15.3)\end{array}$} & & \multirow[t]{3}{*}{$\begin{array}{l}4.7(3.8 \\
6.1)\end{array}$} & & \multirow[t]{3}{*}{$\begin{array}{l}8.9(7.0 \\
11.3)\end{array}$} & & & \\
\hline & $\begin{array}{l}257 \\
(24.2)\end{array}$ & & & & & & & & \\
\hline & $\begin{array}{l}484 \\
(75.7)\end{array}$ & & & & & & & & \\
\hline \multirow{3}{*}{$\begin{array}{l}\text { Basic } \\
\text { Limited } \\
\text { No facility }\end{array}$} & $\begin{array}{l}574 \\
(12.8)\end{array}$ & $\begin{array}{l}9.6(7.4 \\
12.3)\end{array}$ & \multirow[t]{3}{*}{$<0.01$} & $\begin{array}{l}2.0(1.2 \\
3.7)\end{array}$ & \multirow[t]{3}{*}{0.20} & $\begin{array}{l}7.1(5.3, \\
9.6)\end{array}$ & \multirow[t]{3}{*}{$<0.01$} & $\begin{array}{l}16.7(6.8, \\
11.8)\end{array}$ & \multirow[t]{3}{*}{$<0.01$} \\
\hline & $\begin{array}{l}935 \\
(20.8)\end{array}$ & \multirow[t]{2}{*}{$\begin{array}{l}13.7(12.5 \\
14.5) 16.3 \\
(14.7,18.7)\end{array}$} & & $\begin{array}{l}2.5(1.6 \\
3.7)\end{array}$ & & $\begin{array}{l}7.3(5.8, \\
9.6)\end{array}$ & & $\begin{array}{l}22.0 \\
(19.5, \\
24.8)\end{array}$ & \\
\hline & $\begin{array}{l}2,990 \\
(66.4)\end{array}$ & & & $\begin{array}{l}2.9(2.4 \\
3.6)\end{array}$ & & $\begin{array}{l}\text { 13.2 (12.0, } \\
14.5)\end{array}$ & & $\begin{array}{l}25.3 \\
(24.8, \\
26.9)\end{array}$ & \\
\hline \multirow{4}{*}{$\begin{array}{l}\text { Shoe wearing at } \\
\text { interview } \\
\text { Yes } \\
\text { No }\end{array}$} & & $\begin{array}{l}12.9(11.7 \\
14.3)\end{array}$ & 0.18 & $\begin{array}{l}2.9(2.4 \\
3.7)\end{array}$ & 0.26 & $\begin{array}{l}8.3(7.3, \\
9.4)\end{array}$ & $<0.01$ & $\begin{array}{l}19.8 \\
(18.3, \\
214)^{\prime}\end{array}$ & $<0.01$ \\
\hline & & $14.1(12.9$ & & $2.5(1.6$ & & $11.5(10.1$ & & & \\
\hline & $(12.5)$ & & & & & & & $\begin{array}{l}21.4 \\
(21.9,\end{array}$ & \\
\hline & $\begin{array}{l}4,143 \\
(27.4)\end{array}$ & & & & & & & & \\
\hline
\end{tabular}

* P values were calculated using Cochran-Mantel-Haenszel Statistics (Based on Table Scores)

*** Improved sources based on definitions established by the UNICEF and WHO Joint Monitoring Program (see Table 1)

Table 3. Bivariate analysis of schistosomiasis by respondent characteristics and household WaSHT 


\begin{tabular}{|c|c|c|c|c|c|c|c|c|c|}
\hline Characteristics & $\begin{array}{l}\text { Total } \\
\mathrm{N}(\%)\end{array}$ & $\begin{array}{l}\text { S. } \\
\text { mansoni by } \\
\text { Kato Katz } \\
\left(\begin{array}{l}n=129) \% \\
(95 \% \mathrm{Cl})\end{array}\right.\end{array}$ & $P *$ & $\begin{array}{l}S . \\
\text { mansoni } \\
\text { POC-CCA } \\
\text { tr+ } \\
(n=3,251) \\
\%(95 \% \\
\text { Cl) }\end{array}$ & $\mathrm{P*}$ & $\begin{array}{l}S . \\
\text { mansoni } \\
\text { POC-CCA } \\
\text { tr- } \\
(n=1,867) \\
\%(95 \% \\
\text { Cl) }\end{array}$ & $\mathrm{P*}$ & $\begin{array}{l}\text { Haemastix } \\
\text { positive } \\
\neq(\mathrm{n}=411) \\
\%(95 \% \mathrm{Cl})\end{array}$ & P* \\
\hline Male & $\begin{array}{l}7,249 \\
(48.9)\end{array}$ & $0.9(0.7,1.1)$ & 0.86 & $\begin{array}{l}22.6 \\
(21.0 \\
24.4)\end{array}$ & $<0.01$ & $\begin{array}{l}14.5 \\
(13.0, \\
16.1)\end{array}$ & $<0.01$ & $\begin{array}{l}2.4(2.1 \\
2.8)\end{array}$ & 0.02 \\
\hline Female & $\begin{array}{l}7,719 \\
(51.1)\end{array}$ & $0.8(0.7,1.1)$ & & $\begin{array}{l}18.1 \\
(16.5, \\
19.8)\end{array}$ & & $\begin{array}{l}11.5 \\
(10.2, \\
12.9)\end{array}$ & & $\begin{array}{l}3.1(2.7 \\
3.5)\end{array}$ & \\
\hline \multicolumn{10}{|c|}{ Age group (years) } \\
\hline $0-4$ & $\begin{array}{l}1,527 \\
(10.1)\end{array}$ & $0.6(0.3,1.1)$ & 0.04 & $\begin{array}{l}22.6 \\
(19.7 \\
25.7)\end{array}$ & $<0.01$ & $\begin{array}{l}13.1 \\
(10.8 \\
15.7)\end{array}$ & $<0.01$ & $\begin{array}{l}2.4(1.7 \\
3.3)\end{array}$ & 0.02 \\
\hline $5-14$ & $\begin{array}{l}4,660 \\
(30.8)\end{array}$ & $1.9(0.9,1.5)$ & & $\begin{array}{l}25.2 \\
(22.7 \\
27.9)\end{array}$ & & $\begin{array}{l}17.5 \\
(15.3 \\
19.9)\end{array}$ & & $\begin{array}{l}2.3(1.9 \\
2.8)\end{array}$ & \\
\hline $15-20$ & $\begin{array}{l}2,760 \\
(18.2)\end{array}$ & $1.0(0.7,1.4)$ & & $\begin{array}{l}23.2 \\
(20.2 \\
26.5)\end{array}$ & & $\begin{array}{l}16.4 \\
(13.8, \\
19.4)\end{array}$ & & $\begin{array}{l}3.0(2.4 \\
3.7)\end{array}$ & \\
\hline $21-35$ & $\begin{array}{l}3,332 \\
(22.0)\end{array}$ & $0.6(0.4,0.9)$ & & $\begin{array}{l}17.3 \\
(15.0 \\
19.9)\end{array}$ & & $\begin{array}{l}10.0 \\
(8.24 \\
12.2)\end{array}$ & & $\begin{array}{l}3.0(2.5, \\
3.7)\end{array}$ & \\
\hline$>36$ & $\begin{array}{l}2,686 \\
(17.8)\end{array}$ & $0.6(0.4,1.0)$ & & $\begin{array}{l}12.8 \\
(10.7 \\
15.2)\end{array}$ & & $\begin{array}{l}7.47(5.9 \\
9.5)\end{array}$ & & $\begin{array}{l}3.2(2.6 \\
3.9)\end{array}$ & \\
\hline Total & 14,968 & $0.9(0.5,1.6)$ & & $\begin{array}{l}21.6 \\
(20.2- \\
21.7)\end{array}$ & & $\begin{array}{l}13.3 \\
(12.6, \\
13.6)\end{array}$ & & $\begin{array}{l}2.8(2.3, \\
3.4)\end{array}$ & \\
\hline Mean epg* & - & 0.76 & & - & & - & & $0.46^{\star \star \star}$ & \\
\hline $\begin{array}{l}\text { Mod/Heavy } \\
\text { Infection N (\%) }\end{array}$ & & $11(8.5)$ & & - & & - & & $0 * \star \star$ & \\
\hline
\end{tabular}

Acronyms: $\mathrm{Cl}$, confidence interval. $\mathrm{Tr}+$, trace positive $\mathrm{Tr}-$, trace negative.

Notes: Estimates weighted to adjust for non-response/non-availability of data on infections, $95 \% \mathrm{Cl}$ calculated using Taylor linearization method to account for clustering within communities.

‡ Based on Haemastix test for blood in urine as proxy for infection. S. haematobium related findings are based on haemastix positive results and not UF.

* Arithmetic mean intensity calculated for those positive only. 


\begin{tabular}{|c|c|c|c|c|c|c|c|c|c|}
\hline Characteristics & $\begin{array}{l}\text { Total } \\
\mathrm{N}(\%)\end{array}$ & $\begin{array}{l}\text { S. } \\
\text { Mansoni by } \\
\text { Kato Katz } \\
(n=129) \\
\%(95 \% \mathrm{Cl})\end{array}$ & $\mathbf{P}$ & $\begin{array}{l}\text { S. mansoni } \\
\text { POC-CCA } \\
\text { tr+ } \\
(n=3,251) \% \\
(95 \% \mathrm{Cl})\end{array}$ & $\mathbf{P}$ & $\begin{array}{l}S . \\
\text { mansoni } \\
\text { POC-CCA } \\
\text { tr- } \\
(n=1,867) \\
\%(95 \% \\
\text { Cl) }\end{array}$ & $\mathbf{P}$ & $\begin{array}{l}\text { Haemastix } \\
\text { positive } \\
\neq(n=411) \\
\%(95 \% \mathrm{Cl})\end{array}$ & $\mathbf{P}$ \\
\hline \multicolumn{10}{|c|}{ Household drinking water source ${ }^{\star *}(n=6,637)$} \\
\hline \multirow{3}{*}{$\begin{array}{l}\text { Has improved } \\
\text { drinking water } \\
\text { Yes } \\
\text { No }\end{array}$} & & $\begin{array}{l}1.7(1.3, \\
2.0)\end{array}$ & \multirow[t]{3}{*}{0.19} & $\begin{array}{l}20.9(19.5 \\
22.2)\end{array}$ & \multirow[t]{3}{*}{0.14} & $\begin{array}{l}13.2 \\
(12.5 \\
14.4)\end{array}$ & \multirow[t]{3}{*}{$<0.01$} & & \multirow[t]{3}{*}{0.10} \\
\hline & $\begin{array}{l}5,201 \\
(78.7)\end{array}$ & \multirow[t]{2}{*}{$\begin{array}{l}1.2(0.8 \\
1.5)\end{array}$} & & \multirow[t]{2}{*}{$\begin{array}{l}19.8(18.4, \\
21.1)\end{array}$} & & \multirow[t]{2}{*}{$\begin{array}{l}16.2 \\
(15.3 \\
17.7)\end{array}$} & & $\begin{array}{l}3.1(2.7 \\
3.6)\end{array}$ & \\
\hline & $\begin{array}{l}1,408 \\
(21.3)\end{array}$ & & & & & & & $\begin{array}{l}2.5(1.8 \\
3.4)\end{array}$ & \\
\hline \multirow{3}{*}{$\begin{array}{l}<30 \mathrm{~min} \text { to } \\
\text { water } \\
\text { Yes } \\
\text { No }\end{array}$} & & $\begin{array}{l}1.0(0.7 \\
1.4)\end{array}$ & $<0.01$ & & \multirow[t]{3}{*}{$<0.01$} & & \multirow[t]{3}{*}{$<0.01$} & $\begin{array}{l}3.0(2.5 \\
3.7)\end{array}$ & \multirow[t]{3}{*}{0.52} \\
\hline & $\begin{array}{l}3,323 \\
(50.7)\end{array}$ & \multirow[t]{2}{*}{$\begin{array}{l}2.1(1.5, \\
2.6)\end{array}$} & & $\begin{array}{l}16.5(15.0 \\
18.2)\end{array}$ & & $\begin{array}{l}9.7 \\
(8.5,11.1)\end{array}$ & & \multirow[t]{2}{*}{$\begin{array}{l}2.7(2.2, \\
3.4)\end{array}$} & \\
\hline & $\begin{array}{l}3,314 \\
(49.9)\end{array}$ & & & $\begin{array}{l}23.9(21.7 \\
26.3)\end{array}$ & & $\begin{array}{l}16.1 \\
(15.2 \\
17.6)\end{array}$ & & & \\
\hline \multirow{4}{*}{$\begin{array}{l}\text { Basic } \\
\text { Limited } \\
\text { Unimproved } \\
\text { Surface water }\end{array}$} & $\begin{array}{l}2,716 \\
(41.1)\end{array}$ & $\begin{array}{l}0.9 \\
1.3)\end{array}$ & $<0.01$ & $\begin{array}{l}16.9(15.2 \\
18.8)\end{array}$ & \multirow[t]{4}{*}{0.06} & $\begin{array}{l}9.6(8.3 \\
11.1)\end{array}$ & \multirow[t]{4}{*}{0.01} & $\begin{array}{l}3.10(2.5 \\
3.8)\end{array}$ & \multirow[t]{4}{*}{0.05} \\
\hline & $\begin{array}{l}2,485 \\
(37.6)\end{array}$ & $\begin{array}{l}2.5(0.6 \\
3.3)\end{array}$ & & $\begin{array}{l}24.8(22.8 \\
27.0)\end{array}$ & & $\begin{array}{l}16.8 \\
(15.1 \\
18.7)\end{array}$ & & $\begin{array}{l}3.10(2.5 \\
3.9)\end{array}$ & \\
\hline & $\begin{array}{l}832 \\
(12.6)\end{array}$ & $\begin{array}{l}1.3(0.7 \\
3.2)\end{array}$ & & $\begin{array}{l}14.8(11.7 \\
18.6)\end{array}$ & & \multirow{2}{*}{$\begin{array}{l}9.7(7.2, \\
13.0) \\
12.5(9.5 \\
16.4)\end{array}$} & & $\begin{array}{l}1.38(0.8 \\
2.5)\end{array}$ & \\
\hline & $\begin{array}{l}576 \\
(8.72)\end{array}$ & $\begin{array}{l}1.0(0.5 \\
2.3)\end{array}$ & & $\begin{array}{l}19.2(15.5 \\
23.6)\end{array}$ & & & & $\begin{array}{l}2.51(1.5 \\
4.2)\end{array}$ & \\
\hline \multirow{3}{*}{$\begin{array}{l}\text { Treats water } \\
\text { with chlorine } \\
\text { Yes }\end{array}$} & & $\begin{array}{l}3.4(1.9 \\
4.5)\end{array}$ & 0.08 & $\begin{array}{l}\text { 19.1 (15.1, } \\
23.5)\end{array}$ & \multirow[t]{3}{*}{0.05} & $\begin{array}{l}10.9 \\
(8.4,14.2)\end{array}$ & \multirow[t]{3}{*}{0.19} & & \multirow[t]{3}{*}{0.63} \\
\hline & $\begin{array}{l}147 \\
(7.1)\end{array}$ & $\begin{array}{l}2.4(1.5 \\
4.1)\end{array}$ & & $\begin{array}{l}\text { 16.1 (14.6, } \\
18.0)\end{array}$ & & $\begin{array}{l}9.6(7.1 \\
12.9)\end{array}$ & & $\begin{array}{l}0.7(0.6, \\
0.8)\end{array}$ & \\
\hline & $\begin{array}{l}1,930 \\
(92.9)\end{array}$ & & & & & & & $\begin{array}{l}0.6(0.5 \\
0.7)\end{array}$ & \\
\hline
\end{tabular}




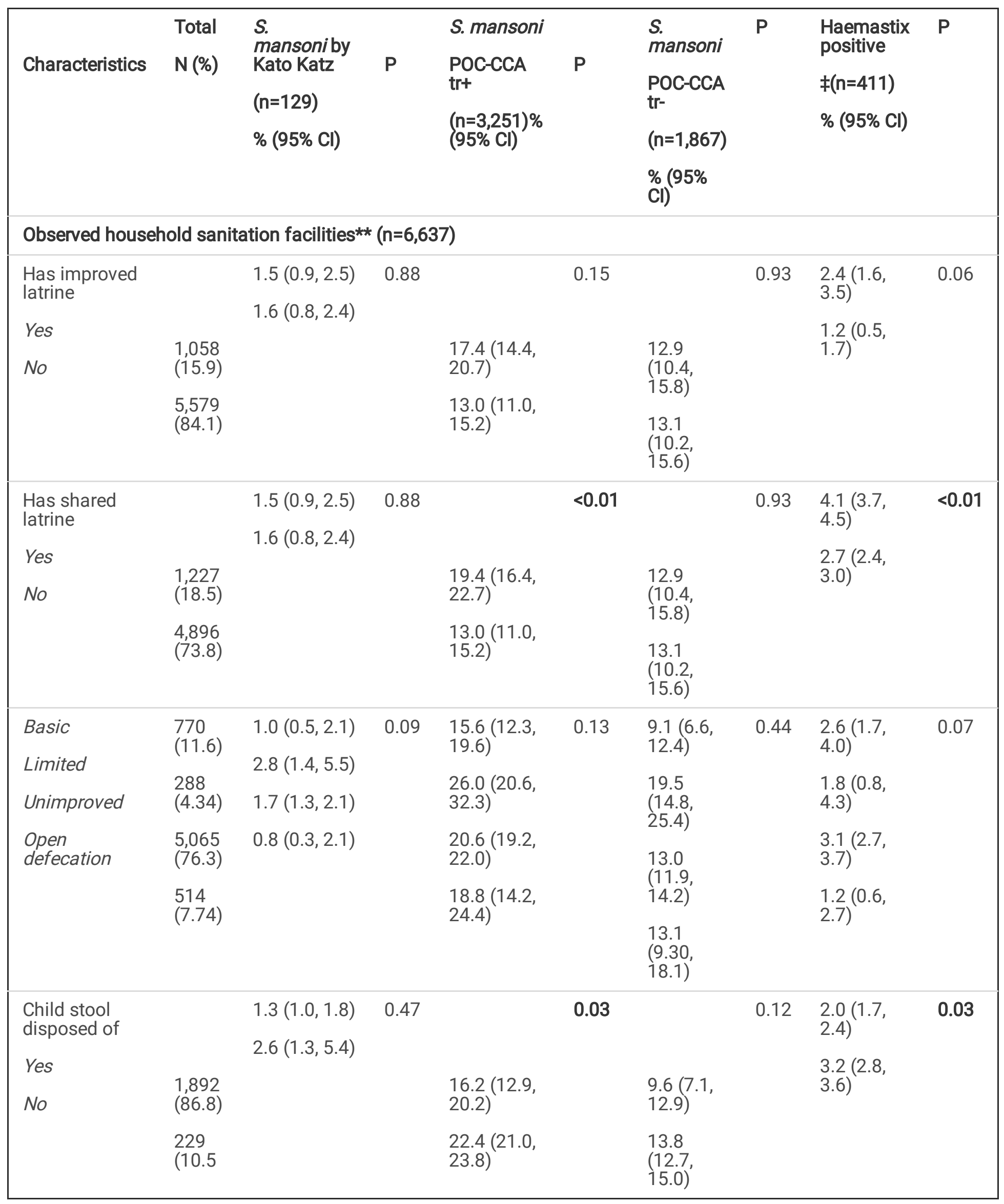




\begin{tabular}{|c|c|c|c|c|c|c|c|c|c|}
\hline Characteristics & $\begin{array}{l}\text { Total } \\
\text { N (\%) }\end{array}$ & $\begin{array}{l}S . \\
\text { mansoni by } \\
\text { Kato Katz } \\
(n=129) \\
\%(95 \% \mathrm{Cl})\end{array}$ & $\mathbf{P}$ & $\begin{array}{l}S . \\
\text { mansoni } \\
\text { POC-CCA } \\
\text { tr+ } \\
(n=3,251) \\
\%(95 \% \\
\text { Cl) }\end{array}$ & $\mathbf{P}$ & $\begin{array}{l}S . \\
\text { mansoni } \\
\text { POC-CCA } \\
\text { tr- } \\
(\mathrm{n}=1,867) \\
\%(95 \% \\
\mathrm{Cl})\end{array}$ & $\mathbf{P}$ & $\begin{array}{l}\text { Haemastix } \\
\text { positive } \\
\neq(n=411) \\
\%(95 \% \mathrm{Cl})\end{array}$ & $\mathbf{P}$ \\
\hline Observed householc & handwa: & hing facilities* & $(n=6,6$ & & & & & & \\
\hline $\begin{array}{l}\text { Handwashing }<3 \mathrm{~m} \\
\text { from latrine }\end{array}$ & & $\begin{array}{l}2.5(1.2 \\
5.3)\end{array}$ & 0.06 & & 0.01 & & $<0.01$ & $\begin{array}{l}3.9(3.4 \\
6.1)\end{array}$ & 0.03 \\
\hline $\begin{array}{l}\text { Yes } \\
\text { No }\end{array}$ & $\begin{array}{l}1,059 \\
(23.5) \\
3,440 \\
(76.5)\end{array}$ & $1.6(1.3,2 . I)$ & & $\begin{array}{l}24.8 \\
(23.2 \\
26.5 \\
20.2 \\
(18.6 \\
21.9)\end{array}$ & & $\begin{array}{l}17.3 \\
(14.3 \\
19.0) \\
13.1 \\
(11.7 \\
14.5)\end{array}$ & & $\begin{array}{l}2.6(2.1, \\
3.3)\end{array}$ & \\
\hline $\begin{array}{l}\text { Basic } \\
\text { Limited } \\
\text { No facility }\end{array}$ & $\begin{array}{l}574 \\
(12.8) \\
935 \\
(20.8) \\
2,990 \\
(66.4)\end{array}$ & $\begin{array}{l}1.9(1.1, \\
3.4) \\
1.9(1.2, \\
3.0) \\
1.7(1.3 \\
2.2)\end{array}$ & 0.88 & $\begin{array}{l}18.2 \\
(14.1, \\
23.1) \\
25.5 \\
(22.4 \\
28.8) \\
20.5 \\
(18.9 \\
22.2)\end{array}$ & 0.01 & $\begin{array}{l}12.2 \\
(8.91, \\
16.6) \\
18.1 \\
(15.5, \\
21.1) \\
13.2 \\
(11.8, \\
14.6)\end{array}$ & $<0.01$ & $\begin{array}{l}0.9(0.4, \\
2.2) \\
4.2(3.1, \\
5.8) \\
2.9(2.3, \\
3.6)\end{array}$ & 0.05 \\
\hline Exposure to Surface & water $(n=$ & $6,637)$ & & & & & & & \\
\hline $\begin{array}{l}\text { Uses surface } \\
\text { water for bathing } \\
\text { Yes } \\
\text { No }\end{array}$ & $\begin{array}{l}795 \\
(38.3) \\
1,282 \\
(61.7)\end{array}$ & $\begin{array}{l}3.1(2.5, \\
3.6) \\
2.0(1.7 \\
2.4)\end{array}$ & 0.01 & $\begin{array}{l} \\
16.3 \\
(13.1, \\
19.1)^{\prime} \\
14.2 \\
(10.1, \\
18.1)^{\prime}\end{array}$ & 0.06 & $\begin{array}{l} \\
9.9(8.4, \\
11.6) \\
9.3(7.8, \\
11.0)\end{array}$ & 0.69 & $\begin{array}{l}0.7(0.6, \\
0.8) \\
0.3(0.2, \\
0.4)\end{array}$ & 0.27 \\
\hline $\begin{array}{l}\text { Uses surface } \\
\text { water for clothes } \\
\text { washing } \\
\text { Yes }\end{array}$ & & $\begin{array}{l}2.7(2.4, \\
3.1) \\
1.3(0.9 \\
1.8)\end{array}$ & 0.01 & & 0.07 & & 0.08 & $\begin{array}{l}0.5(0.4 \\
0.6) \\
0.3(0,1.6)\end{array}$ & 0.27 \\
\hline No & $\begin{array}{l}1,188 \\
(27.1) \\
2,077 \\
(72.9)\end{array}$ & & & $\begin{array}{l}13.7 \\
(11.8, \\
15.9) \\
10.5(8.3, \\
12.7)\end{array}$ & & $\begin{array}{l}8.6(6.1, \\
11.0) \\
5.8(3.8, \\
7.7)\end{array}$ & & & \\
\hline
\end{tabular}

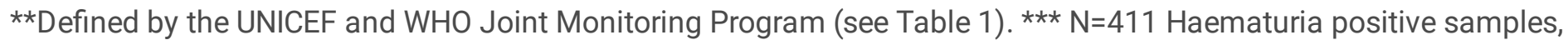
$\mathrm{N}=20$ Urine filtration positive. These are the intensity counts for the UF positive samples only 
Table 4. Prevalence of STH and Schistosomiasis infection by community sanitation coverage

\begin{tabular}{|c|c|c|c|c|c|c|c|}
\hline \multicolumn{8}{|c|}{$\%(95 \% \mathrm{Cl})$ households with improved sanitation } \\
\hline Characteristics & $\mathbf{N}$ & 0 to $<10$ & 10 to $<20$ & 20 to $<30$ & 30 to $<40$ & 40 to $<50$ & $\mathbf{P}$ \\
\hline No. individuals & 6,681 & 2,474 & 2,516 & 932 & 518 & 241 & \\
\hline No. communities & 53 & 14 & 19 & 4 & 4 & 2 & \\
\hline Ascaris prevalence & 916 & $\begin{array}{l}15.1(13.7, \\
16.5)\end{array}$ & $\begin{array}{l}\text { 15.7 (14.3, } \\
17.1)\end{array}$ & $\begin{array}{l}10.1(8.3 \\
12.2)\end{array}$ & $\begin{array}{l}5.8(4.1 \\
8.2)\end{array}$ & $\begin{array}{l}6.4(3.1 \\
10.9)\end{array}$ & $<0.01$ \\
\hline Ascaris mean epg & & $\begin{array}{l}255.7(204 \\
307)\end{array}$ & $\begin{array}{l}267.6(220 \\
314)\end{array}$ & $\begin{array}{l}69.9(37.1 \\
102)\end{array}$ & $\begin{array}{l}29.1(7.5 \\
50.8)\end{array}$ & $\begin{array}{l}85.7(13.0 \\
158)\end{array}$ & $<0.01$ \\
\hline Trichuris prevalence & 178 & $\begin{array}{l}1.50(1.1 \\
2.1)\end{array}$ & $\begin{array}{l}4.57(3.8, \\
5.5)\end{array}$ & $\begin{array}{l}1.93(1.2 \\
3.1)\end{array}$ & $\begin{array}{l}0.77(0.3, \\
2 .)\end{array}$ & $0.66(0,3.4)$ & 0.73 \\
\hline Trichuris mean epg & & $\begin{array}{l}12.6(3.4 \\
21.8)\end{array}$ & $\begin{array}{l}16.9(9.3 \\
24.4)\end{array}$ & $\begin{array}{l}12.5(0 \\
35.3)\end{array}$ & $\begin{array}{l}8.86(0 \\
25.0)\end{array}$ & $\begin{array}{l}21.5(0 \\
51.1)\end{array}$ & $<0.01$ \\
\hline $\begin{array}{l}\text { Hookworm } \\
\text { prevalence }\end{array}$ & 689 & $\begin{array}{l}10.2(9.1 \\
11.5)\end{array}$ & $\begin{array}{l}11.5(10.3, \\
12.8)\end{array}$ & $\begin{array}{l}8.15(6.6 \\
10.1)\end{array}$ & $\begin{array}{l}9.65(7.4 \\
12.5)\end{array}$ & $\begin{array}{l}7.71(4.7 \\
12.0)\end{array}$ & 0.17 \\
\hline $\begin{array}{l}\text { Hookworm mean } \\
\text { epg }\end{array}$ & & $\begin{array}{l}19.9(11.1 \\
28.8)\end{array}$ & $\begin{array}{l}16.7(11.7 \\
21.8)\end{array}$ & $\begin{array}{l}7.44(4.7 \\
10.2)\end{array}$ & $\begin{array}{l}16.1(8.0 \\
24.2)\end{array}$ & $\begin{array}{l}11.5(4.9 \\
18.1)\end{array}$ & $<0.01$ \\
\hline Any STH prevalence & 1,518 & $\begin{array}{l}23.6(22.0 \\
25.4)\end{array}$ & $\begin{array}{l}25.6(24.0 \\
27.4)\end{array}$ & $\begin{array}{l}18.0(15.7 \\
20.6)\end{array}$ & $\begin{array}{l}15.1(12.2 \\
18.4)\end{array}$ & $\begin{array}{l}15.4(11.1 \\
20.8)\end{array}$ & $<0.01$ \\
\hline $\begin{array}{l}\text { S.mansoni (KK) } \\
\text { prevalence }\end{array}$ & 104 & $\begin{array}{l}1.17(0.8, \\
1.7)\end{array}$ & $\begin{array}{l}2.31(1.8 \\
29.7)\end{array}$ & $\begin{array}{l}0.75(0.4 \\
1.6)\end{array}$ & $\begin{array}{l}1.93(1.0 \\
3.6)\end{array}$ & 0 & 0.62 \\
\hline $\begin{array}{l}\text { S.mansoni (KK) } \\
\text { mean epg }\end{array}$ & & $\begin{array}{l}0.33(0.1 \\
0.5)\end{array}$ & $\begin{array}{l}1.14(0.8 \\
1.5)\end{array}$ & $\begin{array}{l}6.71(0.5 \\
19.2)\end{array}$ & $\begin{array}{l}0.74(0.2, \\
1.2)\end{array}$ & 0 & 0.59 \\
\hline S.mansoni (POCTr+) & 844 & $\begin{array}{l}19.2(17.3 \\
21.2)\end{array}$ & $\begin{array}{l}22.5(20.6 \\
24.5)\end{array}$ & $\begin{array}{l}\text { 13.3 (10.7, } \\
16.3)\end{array}$ & $\begin{array}{l}36.4(29.1 \\
44.4)\end{array}$ & $\begin{array}{l}14.0(9.2 \\
20.7)\end{array}$ & 0.99 \\
\hline S.haematobium & 185 & $\begin{array}{l}2.42(1.9 \\
3.1)\end{array}$ & $\begin{array}{l}3.66(29.8 \\
4.5)\end{array}$ & $\begin{array}{l}2.41 \\
3.6)\end{array}$ & $\begin{array}{l}1.33(0.6 \\
2.9)\end{array}$ & $\begin{array}{l}4.14(2.2 \\
7.5)\end{array}$ & 0.87 \\
\hline
\end{tabular}

Table 5. Prevalence of STH and Schistosomiasis infection by community access to improved drinking water 


\begin{tabular}{|c|c|c|c|c|c|c|c|}
\hline \multirow[b]{2}{*}{ Characteristics } & \multirow[b]{2}{*}{$\mathbf{N}$} & \multicolumn{6}{|c|}{$\%(95 \% \mathrm{Cl})$ households with access to improved drinking water } \\
\hline & & 0 to $<10$ & 10 to $<20$ & $20-$ to $<30$ & 30 to $<40$ & 40 to $<60$ & $\mathbf{P}$ \\
\hline No. individuals & 6,681 & 2,474 & 2,516 & 932 & 518 & 241 & \\
\hline No. communities & 53 & 14 & 19 & 4 & 4 & 2 & \\
\hline Ascaris prevalence & 916 & $\begin{array}{l}49.3(31.3 \\
77.9)\end{array}$ & $\begin{array}{l}17.4(15.1 \\
19.9)\end{array}$ & $\begin{array}{l}15.0(12.4 \\
18.1)\end{array}$ & $\begin{array}{l}12.1(8.9 \\
16.2)\end{array}$ & $\begin{array}{l}\text { 14.6 (13.1, } \\
16.3)\end{array}$ & $<0.01$ \\
\hline Ascaris mean epg & & $\begin{array}{l}355.5(217 \\
466)\end{array}$ & $\begin{array}{l}262.3(167 \\
357)\end{array}$ & $\begin{array}{l}354.3(242, \\
466)\end{array}$ & $\begin{array}{l}139.0(36.6 \\
241)\end{array}$ & $\begin{array}{l}175.4(137 \\
213)\end{array}$ & $<0.01$ \\
\hline Trichuris prevalence & 178 & $\begin{array}{l}5.3(3.8 \\
7.4)\end{array}$ & $\begin{array}{l}1.9(1.2 \\
2.9)\end{array}$ & $\begin{array}{l}2.8(3.8 \\
17.7)\end{array}$ & $\begin{array}{l}2.2(1.1 \\
4.6)\end{array}$ & $\begin{array}{l}3.3(2.6 \\
4.2)\end{array}$ & 0.74 \\
\hline Trichuris mean epg & & $1.7(0,4.9)$ & $\begin{array}{l}12.4(1.1 . \\
23.7)\end{array}$ & $4.6(0,9.7)$ & $\begin{array}{l}6.6(2.4 \\
10.7)\end{array}$ & $\begin{array}{l}13.1(6.9 \\
29.6)\end{array}$ & 0.01 \\
\hline $\begin{array}{l}\text { Hookworm } \\
\text { prevalence }\end{array}$ & 689 & $\begin{array}{l}28.9(20.6 \\
40.4)\end{array}$ & $\begin{array}{l}10.2(7.27 \\
14.0)\end{array}$ & $\begin{array}{l}8.8(7.2 \\
10.7)\end{array}$ & $\begin{array}{l}6.9(5.9 \\
8.1)\end{array}$ & $\begin{array}{l}5.27(3.3 \\
7.4)\end{array}$ & $<0.01$ \\
\hline $\begin{array}{l}\text { Hookworm mean } \\
\text { epg }\end{array}$ & & $\begin{array}{l}26.1(5.6 \\
46.5)\end{array}$ & $\begin{array}{l}19.2(4.1 \\
34.2)\end{array}$ & $\begin{array}{l}8.9(6.1 \\
11.7)\end{array}$ & $\begin{array}{l}7.1(3.8 \\
10.4)\end{array}$ & $\begin{array}{l}5.84(3.6, \\
8.1)\end{array}$ & $<0.01$ \\
\hline $\begin{array}{l}\text { S.mansoni (KK) } \\
\text { prevalence }\end{array}$ & 104 & $\begin{array}{l}2.8(0.38 \\
17.7)\end{array}$ & $\begin{array}{l}1.1(0.6 \\
2.0)\end{array}$ & 0 & $0.2(0,1.2)$ & $\begin{array}{l}3.37(2.7 \\
42.8)\end{array}$ & 0.39 \\
\hline $\begin{array}{l}\text { S.mansoni (KK) } \\
\text { mean epg }\end{array}$ & & $0.3(0,1.0)$ & $\begin{array}{l}0.4(0.1 \\
0.7)\end{array}$ & $0.3(0,1.0)$ & $4.5(0,10.5)$ & $\begin{array}{l}0.22(0.1 \\
0.4)\end{array}$ & 0.01 \\
\hline S.mansoni (POCTr+) & 844 & $\begin{array}{l}8.5(6.4 \\
11.2)\end{array}$ & $\begin{array}{l}28.9(19.8 \\
40.2)\end{array}$ & $\begin{array}{l}28.9(26.3 \\
31.7)\end{array}$ & $\begin{array}{l}15.3(10.3 \\
22.1)\end{array}$ & $\begin{array}{l}18.5(16.6 \\
20.4)\end{array}$ & $<0.01$ \\
\hline S.haematobium & 185 & $\begin{array}{l}8.3(2.7 \\
23.2)\end{array}$ & $\begin{array}{l}22.1(14.5, \\
33.8)\end{array}$ & $\begin{array}{l}0.7(0.2, \\
2.7)\end{array}$ & $\begin{array}{l}1.0(0.4 \\
2.2)\end{array}$ & $\begin{array}{l}3.1(2.4 \\
4.0)\end{array}$ & $<0.01$ \\
\hline
\end{tabular}

Table 6: Logistic regression of community and household WaSH coverage by STH infection 


\begin{tabular}{|c|c|c|c|c|c|c|c|c|}
\hline Parasite & Sanitation & & OR & $95 \% \mathrm{Cl}$ & $\mathbf{P}$ & AOR & $95 \% \mathrm{Cl}$ & $\mathbf{P}$ \\
\hline \multirow[t]{6}{*}{ Ascaris } & \multirow[t]{3}{*}{ Community } & $<20 \%$ & 1.1 & $0.9,1.2$ & 0.6 & 1.1 & $0.9,1.2$ & 0.5 \\
\hline & & $20-40 \%$ & 0.6 & $0.5,0.8$ & $<0.01$ & 0.6 & $0.5,0.8$ & $<0.01$ \\
\hline & & $>40 \%$ & 0.4 & $0.2,0.5$ & $<0.01$ & 0.4 & $0.2,0.5$ & $<0.01$ \\
\hline & \multirow[t]{3}{*}{ Household } & Basic & 1.0 & $0.7,1.4$ & 0.9 & 1.2 & $0.9,1.7$ & 0.3 \\
\hline & & Limited & 1.0 & $0.7,1.5$ & 1.0 & 1.3 & $0.8,2.0$ & 0.3 \\
\hline & & Unimproved & 1.1 & $0.8,1.4$ & 0.5 & 1.1 & $0.8,1.4$ & 0.5 \\
\hline \multirow[t]{6}{*}{ Trichuris } & \multirow[t]{3}{*}{ Community } & $<20 \%$ & 3.2 & $2.2,4.6$ & $<0.01$ & 3.3 & $2.2,4.8$ & $<0.01$ \\
\hline & & $20-40 \%$ & 1.3 & $0.7,2.3$ & 0.4 & 1.4 & $0.8,2.6$ & 0.2 \\
\hline & & $>40 \%$ & 0.5 & $0.2,1.4$ & 0.2 & 0.6 & $0.2,1.6$ & 0.8 \\
\hline & \multirow[t]{3}{*}{ Household } & Basic & 0.9 & $0.4,2.0$ & 0.8 & 0.9 & $0.4,2.0$ & 0.8 \\
\hline & & Limited & 1.0 & $0.4,2.7$ & 1.0 & 1.0 & $0.3,2.6$ & 0.9 \\
\hline & & Unimproved & 1.4 & $0.7,2.5$ & 0.4 & 1.4 & $0.7,2.5$ & 0.4 \\
\hline \multirow[t]{6}{*}{ Hookworm } & \multirow[t]{3}{*}{ Community } & $<20 \%$ & 1.2 & $1.0,1.4$ & 0.2 & 1.1 & $1.0,1.3$ & 0.2 \\
\hline & & $20-40 \%$ & 0.8 & 0.6 .1 .0 & 0.07 & 0.8 & 0.6 .1 .1 & 0.2 \\
\hline & & $>40 \%$ & 0.9 & $0.7,1.3$ & 0.7 & 1.0 & $0.7,1.3$ & 0.8 \\
\hline & \multirow[t]{3}{*}{ Household } & Basic & 1.1 & $0.7,1.9$ & 0.7 & 1.2 & $0.7,2.0$ & 0.6 \\
\hline & & Limited & 1.5 & $1.0,2.2$ & 0.05 & 1.6 & $1.0,2.3$ & 0.03 \\
\hline & & Unimproved & 1.6 & $1.1,2.2$ & 0.01 & 1.6 & $1.1,2.2$ & 0.01 \\
\hline
\end{tabular}

Figures 


\section{PARASITOLOGICAL DATA COLLECTION}

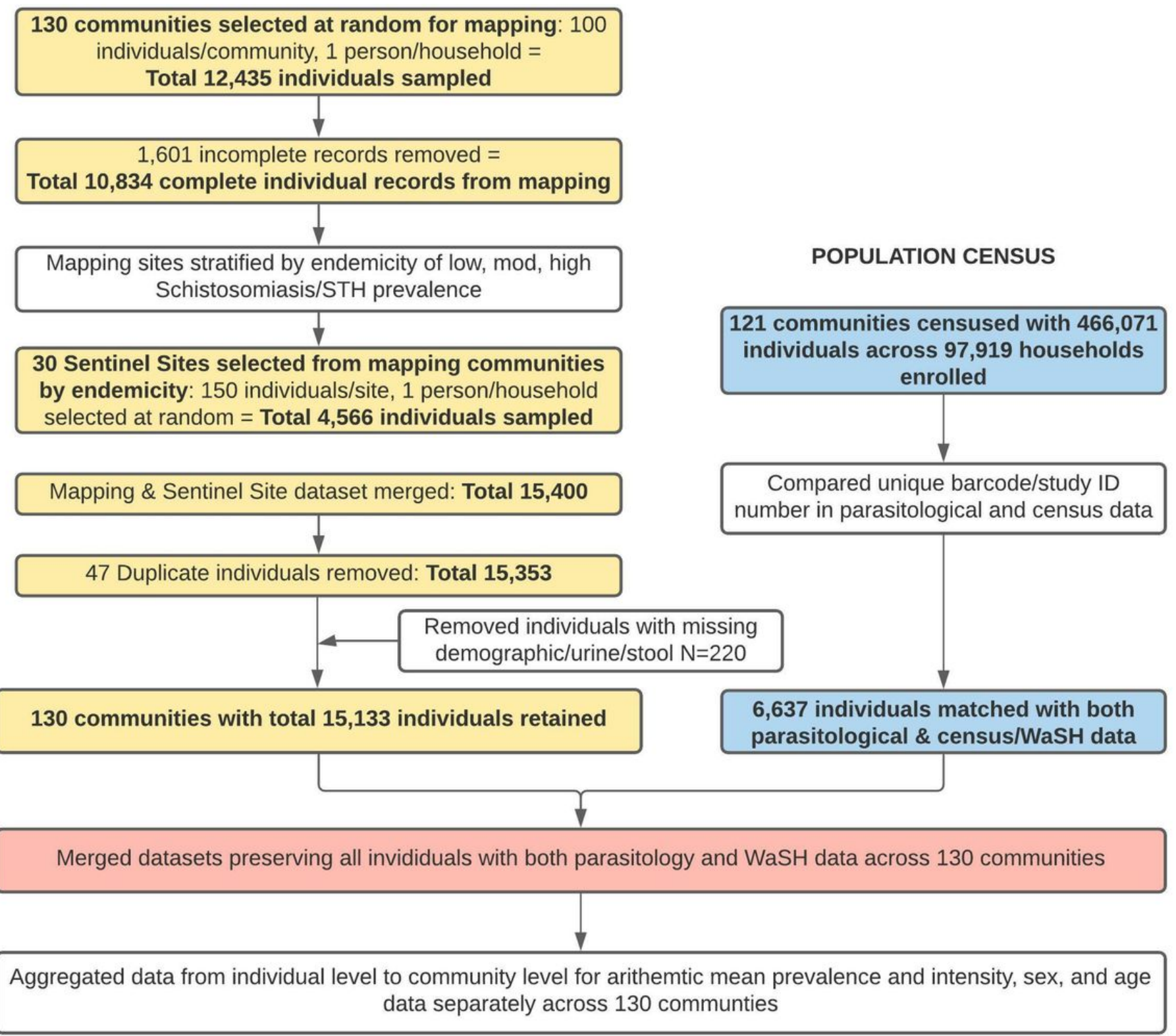

\section{Figure 1}

Flow diagram of village random section and allocation of participants. 


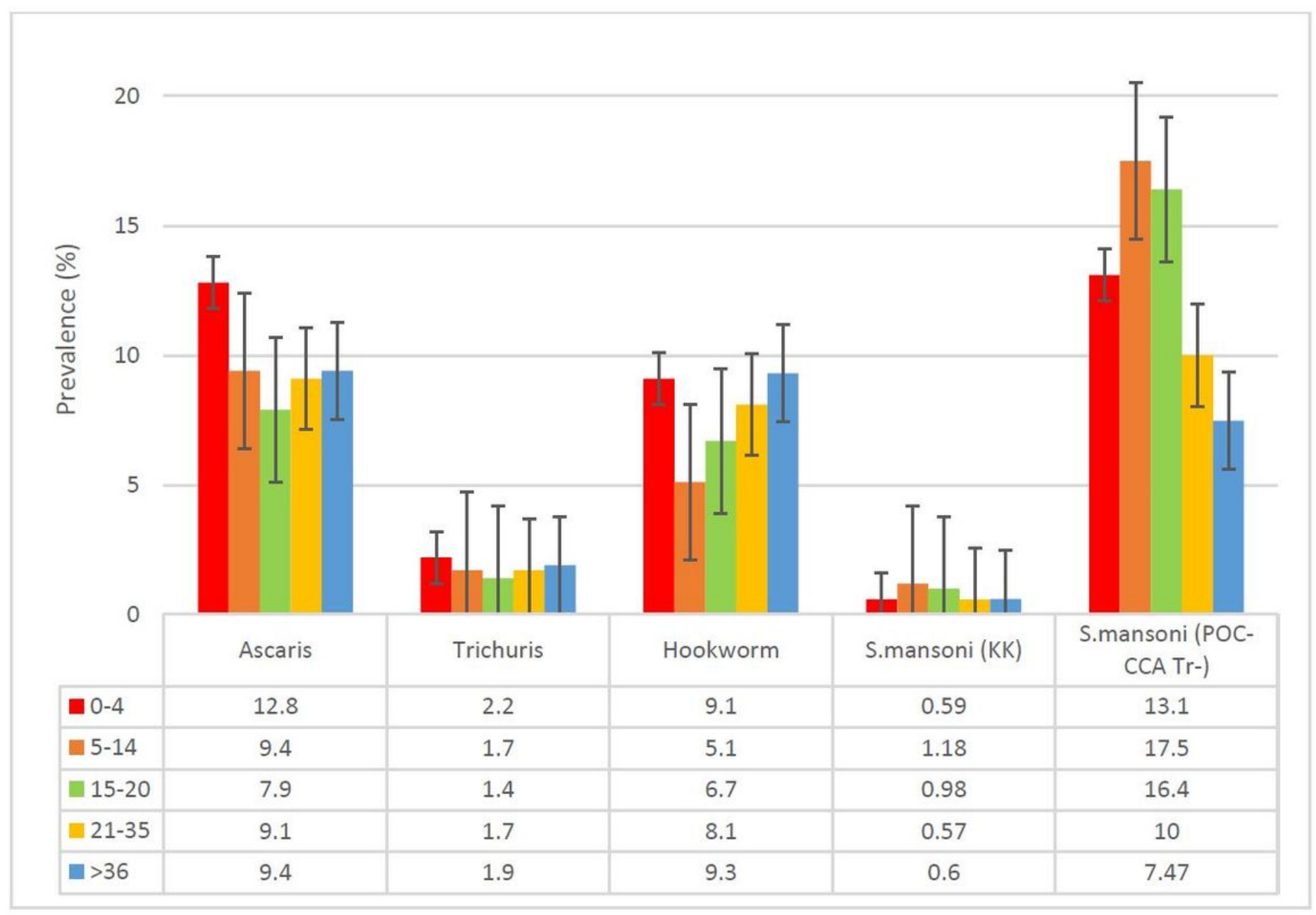

Figure 2

Prevalence of soil-transmitted helminths and schistosomiasis by age group

\section{Supplementary Files}

This is a list of supplementary files associated with this preprint. Click to download.

- IMG25011.jpg 